\title{
A Review of Foodborne Bacterial and Parasitic Zoonoses in Vietnam
}

\author{
Juan J. Carrique-Mas and J. E. Bryant \\ Wellcome Trust Major Overseas Programme, Oxford University Clinical Research Unit, Hospital for Tropical Diseases, 764 Vo Van Kiet, W.1, Dist.5, \\ Ho Chi Minh City, Vietnam
}

\begin{abstract}
Vietnam has experienced unprecedented economic and social development in recent years, and the livestock sector is undergoing significant transformations. Although food animal production is still dominated by small-scale 'backyard' enterprises with mixed crop-livestock or livestock-aquatic systems, there is a trend towards more intensive and vertically integrated operations. Changes in animal production, processing and distribution networks for meat and animal products, and the shift from wet markets to supermarkets will undoubtedly impact food safety risks in Vietnam in unforeseen and complex ways. Here, we review the available published literature on bacterial and parasitic foodborne zoonoses (FBZ) in Vietnam. We report on clinical disease burden and pathogen prevalence in animal reservoirs for a number of important FBZ, and outline opportunities for future research.
\end{abstract}

Keywords: Vietnam, foodborne zoonoses, livestock, aquaculture, human-animal interface

\section{INTRODUCTION}

Foodborne zoonoses (FBZ) are human infections transmitted through ingested food and caused by pathogens whose natural reservoir is a vertebrate animal species (Hubalek 2003). In industrialized countries, $20 \%$ people suffer annually from foodborne infections (Hall et al. 2005; Painter et al. 2013); the fraction attributable to zoonotic organisms is $\sim 50 \%$ (Liu et al. 2004, 2006; Chen et al. 2010; EFSA 2012). In Vietnam, suspect outbreaks of foodborne disease are reported to the Vietnam Food Administration (VFA) (http://vfa.gov.vn). In 2011, 148 outbreaks were reported, with 38,915 cases, 3,663 hospitalizations and 27 deaths. In most cases, FBZ aetiologies remain undeter-

Published online: October 26, 2013

Correspondence to: Juan J. Carrique-Mas, e-mail: jcarrique-mas@oucru.org mined, and the relative disease burden compared to other infectious diseases cannot be readily quantified.

Some characteristics of animal production and food consumption habits in Vietnam that may promote zoonotic disease transmission include: (1) high density of both human and animal populations living in close proximity; (2) a predominance of smallholder production systems with mixed species and little/no biosecurity; (3) the presence of abattoirs and wet markets operating with rudimentary hygiene, limited cold chain for distribution and low levels of meat inspection; (3) widespread consumption of raw/undercooked blood, meat, fish, organ tissues, raw leaf vegetables and wild animal products and (4) use of untreated wastewater and sewage for agriculture. For these reasons, Vietnam and South East Asia are often considered a hotspot for emerging infectious diseases (Coker et al. 2011). Indeed, the threat of emerging viral pathogens has 
received significant international attention, while the burden of endemic (predominantly bacterial and parasitic) zoonoses remains largely neglected. Within the last two decades, Vietnam has undergone extraordinary development. Changes underway involve rapid urbanization, intensification of animal production, modernization of food marketing systems and changes in food consumption habits. These changes will undoubtedly have major impacts on human exposures to animal pathogens, and hence the overall risk of zoonotic disease transmission. Despite significant investments in improved disease surveillance systems, information on FBZ is not readily available, and veterinary services are chronically under-resourced. The objectives of this review paper are to highlight knowledge gaps on FBZ and suggest priorities and specific areas for future research.

\section{Methods}

We reviewed the available published literature in English from Vietnam on bacterial and parasitic FBZ from 1991 until January 2013. We searched PubMed for articles on food and waterborne zoonotic pathogens listed by the UK Health Protection Agency (HPA 2013), plus: 'yersiniosis' and 'Yersinia enterocolitica', 'Fasciola', 'fascioliasis', 'Angiostrongylus cantonensis', 'fishborne trematodes' and 'Paragonimus'. Each search term was used in combination with 'Vietnam' and 'Viet Nam'. We also used the same search terms to identify relevant articles published in the following Vietnamese public health and veterinary journals: (1) Tạp chì phòng chống bệnh sốt rét và các bệnh ký sinh trùng (Journal of Prevention of Malaria and Parasitology); (2) Khoa học kỹ thuật thú y (Journal of Veterinary Medicine); (3) Y học tḥ hành (Medical Practice); (4) Y học tp. HCM (Medicine in Ho Chi Minh City); (5) Tạp chí Y học dự phòng (Journal of Preventive Medicine). None of these journals is electronically indexed. Although the emergence of antimicrobial resistance (AMR) is of paramount importance to food safety and public health in Vietnam (Dyar et al. 2012; Lestari et al. 2012), we have chosen not to address AMR, as this topic merits an extensive review on its own. Similarly, due to space limitations, we have not covered viral FBZ. We document available data on diverse FBZ, including human clinical impact and prevalence/ incidence data within animal reservoirs, with a specific focus on the current situation in Vietnam.

\section{BACTERIAL FBZ}

\section{Non-Typhoid Salmonella (NTS)}

Non-typhoidal Salmonella (NTS) infections are caused by serovars of Salmonella enterica other than (non zoonotic) $S$. typhi or S. Paratyphi. Most NTS serovars are presumed to be zoonotic and potentially pathogenic to humans. NTS infections are typically self-resolving gastroenteritis, although complications may occur in children ( $<5$ years), elderly and immunodeficient patients (Pegues and Miller 2010). NTS may infect a wide range of animals (both domestic and wild), but the vast majority do not to cause detectable pathology in the reservoir host.

In Vietnam, improvements in sanitation have resulted in dramatic reductions of typhoid over recent decades. In southern Vietnam, S. typhi cases reduced from 497 in 1994 to 34 in 2008, with a concurrent increase of invasive cases of NTS (from 9 to 24) (Nga et al. 2012). Studies on NTS in humans in Vietnam are summarized in Table 1. NTS prevalence in various farm animals (pre-slaughter) and in slaughter and retail facilities is summarized in Table 2 . Detected levels in meat are high, suggesting widespread contamination during slaughtering/processing. Contaminated fish products likely reflect widespread use of animal/ human sewage in aquaculture. Serovar or molecular data from animals and humans are limited, so it is difficult to establish the main sources of human infection. Epidemiological data suggests that person-to-person transmission plays a major role (Thompson et al. 2012). NTS carriage has been detected in $\sim 5 \%$ of healthy adults (personal communication).

\section{Campylobacteriosis}

Globally, Campylobacter is the single most common human bacterial diarrhoeal pathogen, and together with NTS, account for $\sim 90 \%$ of foodborne bacterial disease. In Vietnam, as in other countries, C. jejuni is the dominant species found in paediatric clinical cases $(\sim 85 \%)$ (Isenbarger et al. 2001), with the remainder due to C. coli.

Reported Campylobacter prevalence in Vietnamese poultry meat ranges from 28 to $31 \%$ ( $\mathrm{Ha}$ and Pham 2006; Luu et al. 2006). A 2005-2006 investigation of Campylobacter spp. at slaughterpoints in five cities worldwide indicated lowest prevalence in Ho Chi Minh City (HCMC) (15.3\%, vs. an overall prevalence of $65.5 \%) ; 74 \%$ were C. lari, $9 \%$ C. coli, $4 \%$ C. jejuni and $13 \%$ other species. 


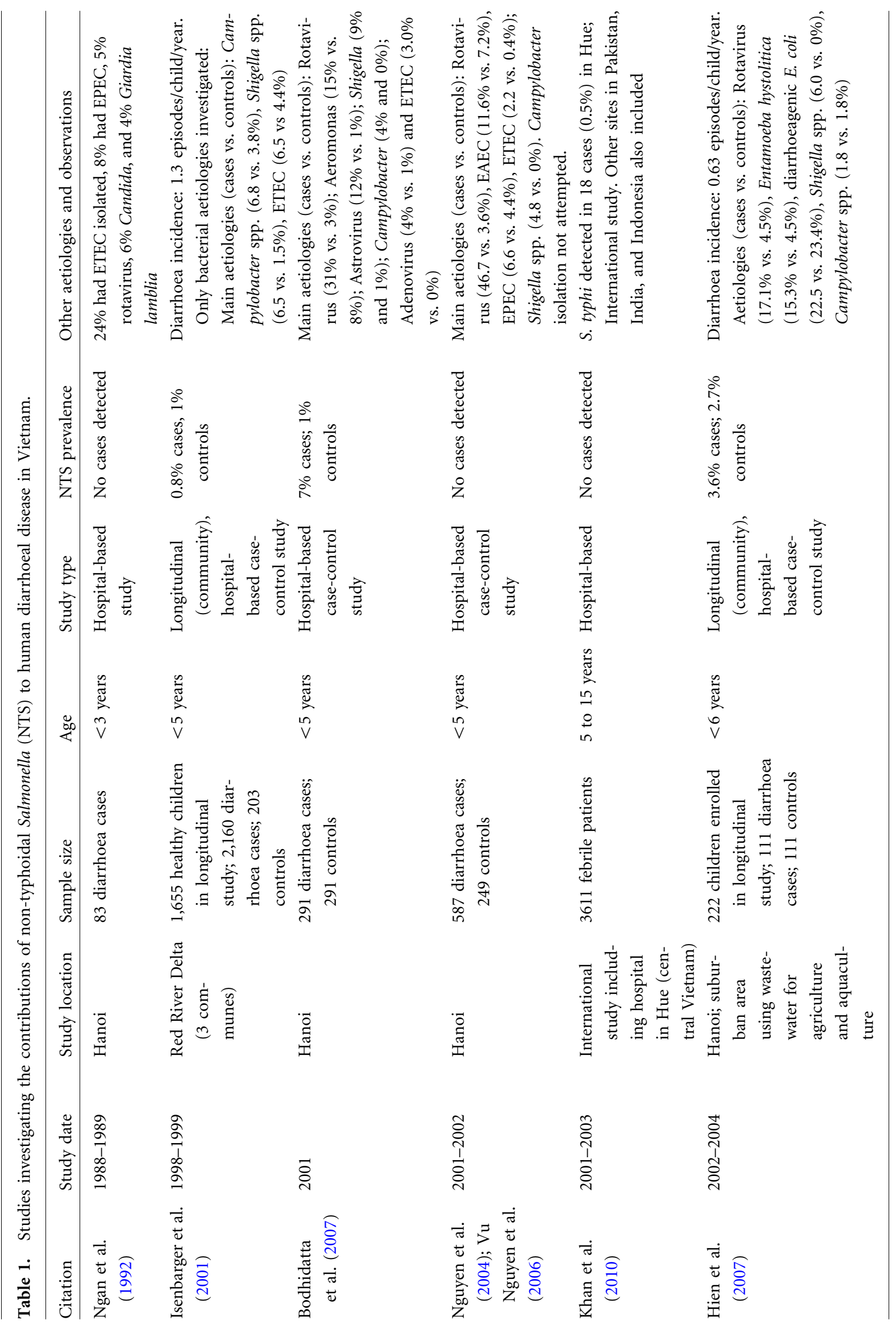




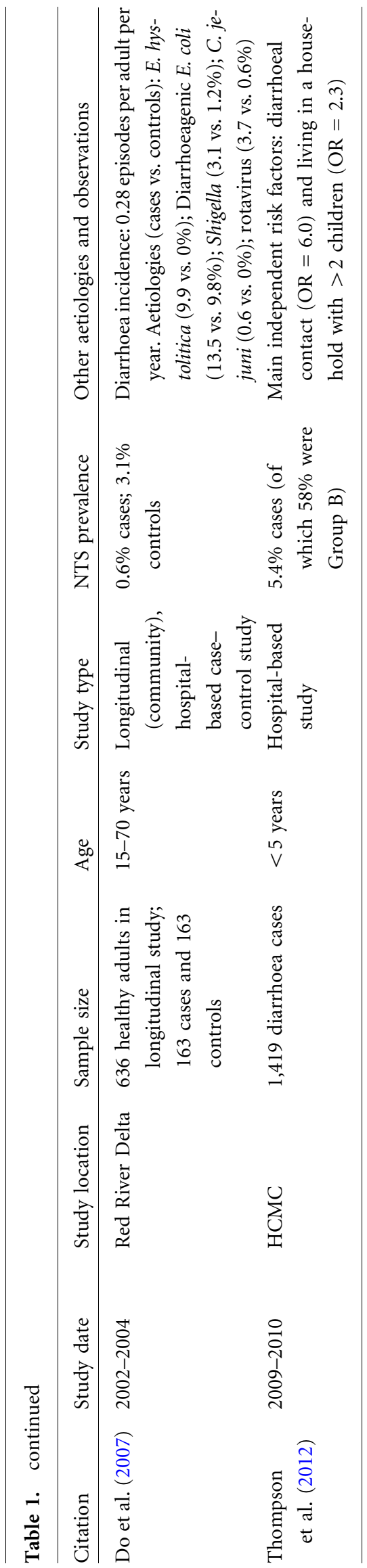

Semi-industrial poultry slaughtering was associated with lower contamination than informal direct slaughter by sellers (Garin et al. 2012). In Vietnam, there are no published data on pre-slaughter (on-farm) prevalence or Campylobacter species diversity.

The relative contribution of Campylobacter and NTS to diarrhoea is not particularly high, and asymptomatic infections appear to be common (Table 1). Given the widespread prevalence of NTS and Campylobacter in food products, and the intense human-animal exposures for most rural Vietnamese, the low incidence of clinical disease may reflect high levels of population immunity.

\section{Listeriosis}

Listeria monocytogenes causes abortion and sepsis-like infection in humans, especially among immunocompromised individuals, neonates, pregnant women and the elderly. Clinical L. monocytogenes infection was confirmed in 2008-2009, among three patients with meningitis in Hanoi (Chau et al. 2010; Tran et al. 2010). Listeriosis has been linked to consumption of unpasteurised soft cheeses, processed meat and fish products. A study of fish and seafood products from Nha Trang Bay (central Vietnam) identified L. monocytogenes in 5.8\% (Beleneva 2011).

There are no data on prevalence of $L$. monocytogenes in meat products in Vietnam, but studies in the region (Thailand) suggest a high prevalence of $L$. monocytogenes in raw meats, especially in those sold in supermarkets (Indrawattana et al. 2011). In Vietnam, meat is increasingly bought from supermarkets, especially in urban areas.

\section{Streptococcus suis}

Streptococcus suis is an emerging human infection in Vietnam. The clinical picture is typically severe, and may involve skin, respiratory, neurological, cardiovascular and gastrointestinal systems. The largest $S$. suis outbreak recorded occurred in China in 2005, with 215 confirmed cases among pig slaughterers (Yu et al. 2006). Aetiological studies in Vietnam of cerebrospinal fluid from $>2,000$ patients (1996-2010) with suspect CNS infection have identified S. suis serotype 2 in $8.9-33.6 \%$ diagnosed patients (Mai et al. 2008; Wertheim et al. 2009b; Ho Dang Trung et al. 2012), confirming S. suis as the most frequent cause of bacterial meningitis in adults. About $66 \%$ patients experienced hearing loss as a sequela (Mai et al. 2008). Serotype 2 accounts for $96 \%$ of human cases, but other 


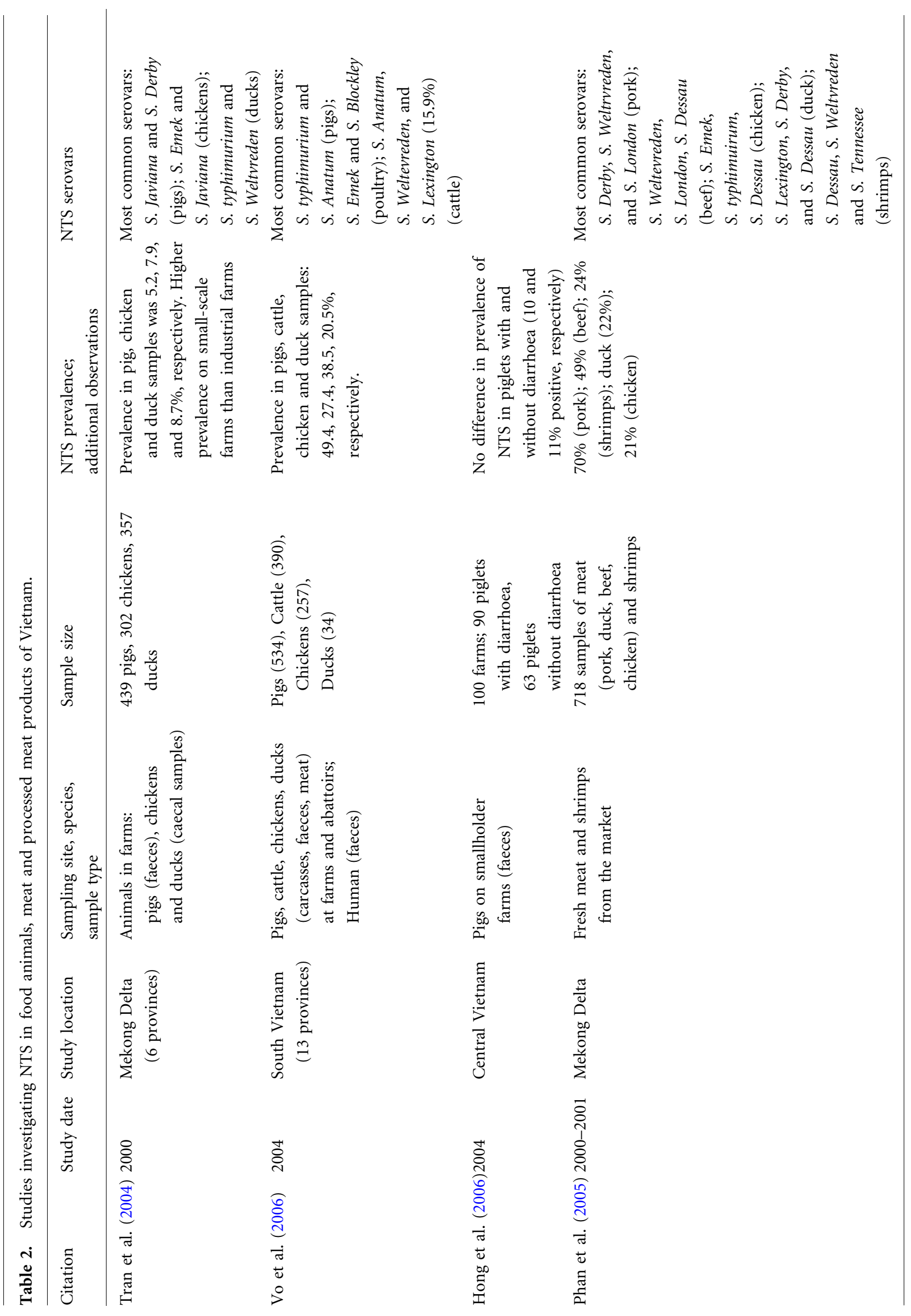




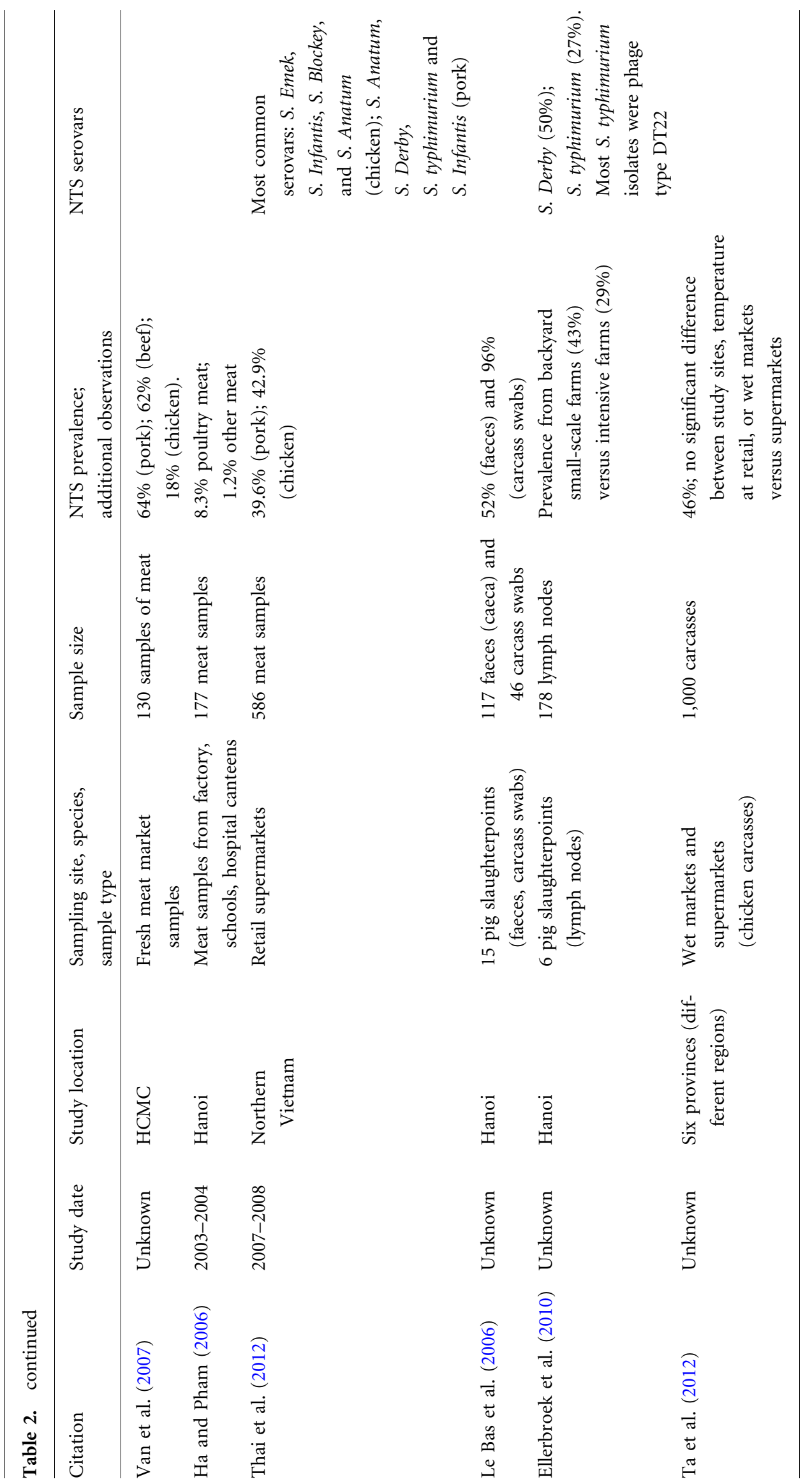


serotypes (i.e. 16, 14) have also occurred (Nghia et al. 2008). A case-control study identified the following risk factors: (1) eating undercooked pig blood/intestine; (2) occupation related to pigs; and (3) exposure to pigs while having skin injuries (Nghia et al. 2011). Due to poorly regulated marketing systems, ill pigs may enter the food chain, thus posing a significant risk to both slaughterhouse workers and consumers. Consumption of pig blood, intestines and organ meats is common in Vietnam (Wertheim et al. 2009a).

Streptococcus suis carriage rates of $41 \%(n=542)$ have been identified in healthy Vietnamese pigs. Serotype 2 appears to be dominant (14\%), followed by serotypes 3, 21, 21 and 16 (Ngo et al. 2011). High numbers of pigs infected with Porcine Respiratory Reproductive Syndrome (PRRS) virus have tested positive for S. suis in blood, indicating concurrent viraemic and bacteraemic infections (Hoa et al. 2013).

\section{Leptospirosis}

Leptospirosis is caused by several pathogenic species within the genus Leptospira. Humans become infected through cuts, skin abrasions or by drinking contaminated water. Symptoms can range from mild, influenza-like illness to severe infection with renal and hepatic failure, pulmonary distress and death (Adler and de la Pena Moctezuma 2010).

Studies of acute jaundice in Hanoi and HCMC from 1993 to 1997 ( $n=550$ patients) reported 8 and 2\% leptospirosis, respectively. The most commonly identified serovars were Seramanga and Bataviae (Laras et al. 2002). A serosurvey in the Mekong Delta reported high seropositivity (21\%) among 36-45 year olds, with detection of Bataviae (21.7\%), Panama (15.2\%), Icterohaemorrhagiae (13.7\%), and Australis (8.7\%). In that study, walking barefoot was a significant risk factor for seropositivity, but not contact with animals (Van et al. 1998). A 2003 survey of children $(n=961)$ in southern Vietnam identified antiLeptospira IgG in $12.8 \%$, a $1.5: 1$ male: female ratio of seropositivity, and significant association with swimming in rivers. Based on IgG seroconversion, a $0.99 \%$ annual incidence was estimated (Thai et al. 2006).

Leptospiras have a broad range of animal reservoirs. Most studies in Vietnam have focused on pigs due to their impact on swine reproduction. In the Mekong Delta, Bratislava, Icterohaemorrhagiae, Automnalis, Grippotyphosa and Pomona are the most common serovars, with higher prevalence in small-scale farms compared to large holdings
(Boqvist et al. 2002a, b). In general, there appears to be little overlap between serovars in pigs and humans; however, there is a paucity of surveillance data on which to judge exposures and epidemiological associations. The diffuse clinical picture and lack of straightforward diagnostics for leptospirosis (Wagenaar et al. 2004; Smythe et al. 2009) hamper adequate case reporting from Vietnam.

\section{PARASITIC FBZ}

\section{Toxoplasmosis}

Toxoplasmosis is caused by the larval stage of the protozoan Toxoplasma gondii. Humans become infected by ingesting cysts (from undercooked meat/viscera), or oocysts released from the definitive host (the domestic cat) that contaminate food, water or the environment. Clinical signs range from mild to severe due to invasion of muscle, brain and eyes. Congenital toxoplasmosis occurs due to primary maternal infection during gestation (Montoya et al. 2010).

In Vietnam, a number of $T$. gondii serosurveys have been conducted (Table 3). Human seroprevalence is not particularly high (1-24\%); in animals it ranges from low/ medium (3\% buffalo, $10 \%$ cattle) to high ( $23 \%$ pigs; $29 \%$ poultry; $50 \%$ domestic dogs). There are no published data on prevalence in domestic cats. Pigs are likely to play a major role in T. gondii infection, since pork is the most commonly consumed meat. In Thailand, a high prevalence in stray dogs has also been reported (Jittapalapong et al. 2007). Domestic dogs may also be relevant to transmission, since stray dogs are often imported from Thailand to supply dog meat restaurants. In southeast Asia, culinary habits (e.g. eating undercooked meat) and low water quality may be a more significant risk factor for $T$. gondii than cat ownership (Nissapatorn et al. 2003).

\section{Cryptosporidiosis}

Cryptosporidiosis is caused by protozoa of the genus Cryptosporidium. Of 20 Cryptosporidium species, seven are zoonotic (Fayer 2004), the most common one being C. parvum bovine genotype 2 . Transmission is through ingested contaminated water and vegetables, although person-to-person transmission has been also documented. Most outbreaks have been attributed to C. parvum and linked to a waterborne source (Clinton White 2010). Studies in Vietnam have not found evidence of Cryptos- 


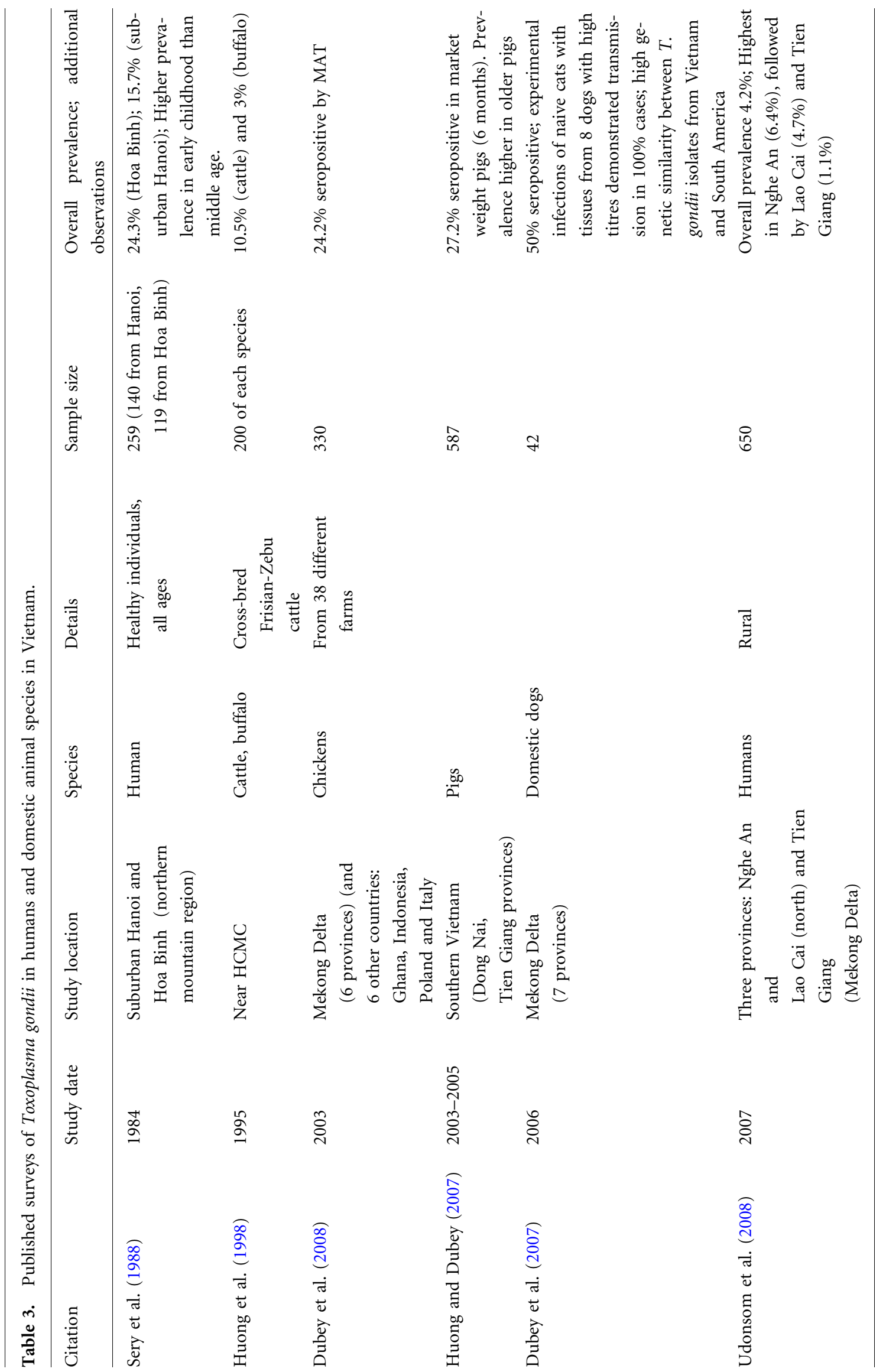


poridium clinical disease among children with diarrhoea (Uga et al. 2005; Bodhidatta et al. 2007).

Cattle are thought to be the most common source of $C$. parvum genotype 2 , although infection of pigs has also been described (Jenkins et al. 2010). A study of 266 cattle in three central provinces found $33.5 \%$ C. parvum positive (Nguyen et al. 2007a). Another study from the Red River Delta failed to detect Cryptosporidium among 68 healthy calves, but found 50\% positive for Giardia (Geurden et al. 2008). A Cryptosporidium prevalence of $18 \%$ among diarrheic pigs of central Vietnam was reported (Nguyen et al. 2012), however, speciation was not performed, thus the implications for zoonotic transmission were unclear. $C$. parvum has been detected in farmed fish from southern Vietnam in association with wastewater used in aquaculture (Gibson-Kueh et al. 2011).

\section{Giardiasis}

Giardia lamblia is a protozoan cause of diarrhoea found in soil, food, and water contaminated with faeces from infected humans or animals. G. lamblia has a very broad host range, and some subtypes/species are zoonotic. Recent molecular analysis of specific genetic assemblages suggests a high degree of host-specificity, with limited potential to infect humans (Xiao and Fayer 2008). A study on children less than 3 years old with severe diarrhoea in Hanoi identified G. lamblia among 2.4\% (Ngan et al. 1992). Healthy people $(N=2,522)$ in north-western Vietnam had a surprisingly high prevalence (4.1\%) (Verle et al. 2003). A study in calves less than 3 months old showed that Giardia spp. were the most prevalent parasites (50\%); further characterization of 17 isolates indicated that all were non-zoonotic G. duodenalis (Geurden et al. 2008). Both Giardia and Cryptosporidium represent a challenge to safe drinking and recreational water supplies, due to their resistance to chlorine and environmental persistence.

\section{Taeniasis/Cysticercosis}

Taeniasis and cysticercosis are distinct disease entities caused by different life stages of Taenia spp. Taeniasis refers to human enteric infection with the adult tapeworm, after ingestion of taenid cysts (cysticerci) present in undercooked beef (T. saginata) and pork (T. solium and T. asiatica). Cysticercosis are infections caused by ingestion of taenid eggs. Over the past decades, incidence of cysticercosis has decreased substantially worldwide owing to improved animal husbandry, sanitation and better meat inspection (Sotelo 2003).

Studies on taeniasis and cysticercosis in humans are shown in Table 4. During the 1990s, approximately 100 150 patients with neurocysticercosis were annually referred to Hanoi hospitals (Ky and Van Chap 2000). In addition, serosurveys published in Vietnamese suggest a large variation in prevalence among adults $(0.2-7.2 \%)$ (Willingham et al. 2003).

Pig infections with cysticerci may result in reduced carcass value or full condemnation. A 1989-1992 study of meat carcasses in Hanoi indicated low prevalence $(<0.1 \%)$. A 1999-2000 swine serosurvey indicated $\sim 10 \%$ prevalence of cysticerci; however, cysts were T. hydatigena, for which the domestic dog is the final host (Dorny et al. 2004). Taenid eggs and T. solium cysts have been found in vegetables and dog meat sold in Hanoi (Uga et al. 2009; Willingham et al. 2010). Eating raw/pickled pork (i.e. 'nem chua') may be a major risk factor, as well as agricultural use of human wastewater as fertilizer (Dorny et al. 2004). To date, T. asiatica has not been reported from pigs in Vietnam, suggesting there may be other non-porcine intermediate hosts (Dorny et al. 2007). It is not yet clear whether $T$. asiatica causes cysticercosis (Galan-Puchades and Fuentes 2009). The presence of both T. saginata and T. asiatica in Vietnam may limit transmission of the more serious $T$. solium infection due to cross-protection (Conlan et al. 2009).

\section{Trichinellosis}

Trichinellosis is caused by ingestion of encysted larvae of the genus Trichinella, predominantly from contaminated pork. T. spiralis is the most common species, found in pigs, wild boars and other species (Pozio et al. 2009). In humans, the clinical spectrum ranges from mild fever to myalgia and fulminating fatal disease. Like cysticercosis, the incidence of Trichinellosis has been decreasing worldwide over the last century. Data on Trichinella from Vietnam are limited to a few reports of sporadic outbreaks ( 25 cases each) reported since 1970 in remote northern provinces (Dien Bien, Yen Bai and Son La), all traced back to consumption of undercooked/fermented pork (Taylor et al. 2009). A 20082009 serosurvey for $T$. spiralis in 1,035 free-roaming pigs reported age-dependent increases in seroprevalence, with overall seropositivity of $20 \%$, and Trichinella larvae in 14.5\% (Thi et al. 2010). 


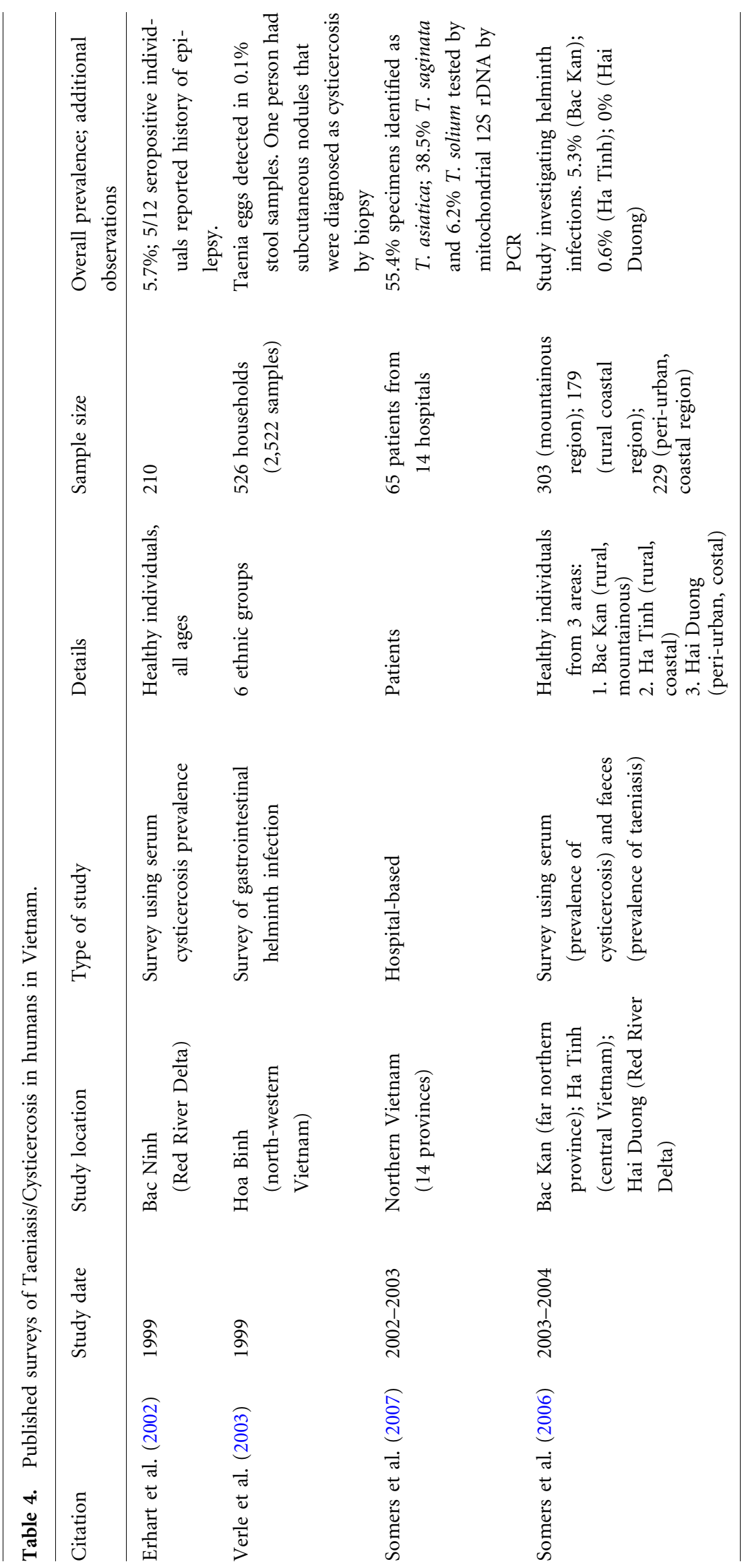




\section{Fascioliasis}

Fascioliasis is caused by liver flukes of two species, Fasciola hepatica and F. gigantica. Humans become infected through ingestion of water or freshwater plants with adherent metacercaria (Mas-Coma 2005; Ashrafi et al. 2006) or juvenile forms (Taira et al. 1997). The parasite requires replication in Lymnea snails as intermediate hosts.

In Vietnam, fascioliasis has been increasingly diagnosed since the 1990s, mostly in ruminant-producing areas during the rainy season (De et al. 2003) (Table 5). Aberrant clinical forms (cutaneous fascioliasis) have been reported in association with F. gigantica (Xuan et al. 2005; Le et al. 2007). A hybrid of F. hepatica and F. gigantica has been reported from humans, cattle (Le et al. 2008) and goats (Nguyen et al. 2009). Parasite burdens are likely to have important economic repercussions for livestock production.

It is unclear whether increasing case numbers of fascioliasis represent disease emergence or improved laboratory diagnostics and reporting. Changes in environmental factors and/or livestock production (i.e. increasing stocking densities, use of cattle faeces as fertilizer) may contribute to transmission (Tran et al. 2001b; De et al. 2003).

\section{Fish-Borne Zoonotic Trematodes (FZT)}

FZT comprise a large group of flukes of the families Heterophyidae, Echinostomatidae and Opistorchiidae (Chai et al. 2005). Adult liver flukes live in the biliary tract of a range of vertebrates. Eggs are released in the environment; the miracidium penetrates freshwater snail tissues, where it develops into free-swimming cercariae that infect cyprinid freshwater fish. Within the fish host, parasites invade muscle and transform into metacercariae that are infectious for humans. Although most human FZT infections are subclinical, Clonorchis sinensis and Opistorchis verrini may cause chronic liver infection, pancreatitis, cholangitis and cancer (Choi et al. 2006; Mayer and Fried 2007). C. sinensis is widely distributed in East Asia and is endemic to the Red River Delta, whereas O. viverrini is present in Laos, Cambodia, Thailand and southern Vietnam.

Approximately, one million people are infected with FZT in Vietnam (Kino et al. 1998). Overall, low to moderate levels of FZT are found within healthy individuals. Epidemiological studies indicate significant geographic variability, associations with culinary habits, and widespread infection of diverse animal species (Table 6). During
2009-2010, an intervention study in 18 fish nurseries introduced snail control by pond draining and treatment of humans and domestic cats. Examination of $\sim 15,000$ fish after 9 weeks of intervention indicated moderate success in reducing fish infection rates with FZT (Hedegaard Clausen et al. 2012). Given that human, pig and poultry excreta are commonly used as fish feed, and that snails and fish are fed to poultry, it is likely that multiple vertebrate species play a role in maintaining FZT transmission. There are strong economic and trade incentives to reduce transmission to promote successful development of aquaculture exports.

\section{Paragonimiasis}

Paragonimiasis is a lower respiratory tract infection caused by lung Paragonimus flukes. Humans become infected through consumption of infective metacercariae from raw or undercooked crustaceans. Eggs are voided by infected people in sputum or faeces; in the environment, the parasite goes through several stages involving snails and then crayfish or crabs as hosts. Symptoms are sometimes mistaken with chronic tuberculosis (Vijayan 2009). Clinical cases in Vietnam have been documented from mountainous regions, linked to consumption of infected crabs (Table 7). Vietnamese domestic dogs and pigs infected with Paragonimus have been reported (Queuche et al. 1997). Species identified from Vietnam include $P$. heterotremus, $P$. vietnamiensis, $P$. proliferus (northern mountainous areas) and P. westermani (central Vietnam) (Doanh et al. 2007, 2008, 2009). In spite of mass screening, treatment and education programmes, paragonimiasis remains a problem in a limited number of areas of the country.

\section{Gnathostomiasis}

Gnathostomiasis occurs wherever consumption of raw fish is common. Human infections are acquired by ingestion of advanced third stage larvae (AL3) of Gnathostoma spp. present in fish species. Humans are paratenic hosts; the larvae commonly migrate through subcutaneous tissues, visceral organs and the central nervous system. G. spinigerum is the most common species in Southeast Asia, usually found in swamp eels (Monopterus albus) (Waikagul and Diaz Camacho 2007).

Until 1998 only three cases of G. spinigerum had been documented in Vietnam; however, introduction of serological tests since then led to hundreds of cases since. A study indicated that $63.8 \%$ had cutaneous and $14.7 \%$ had 


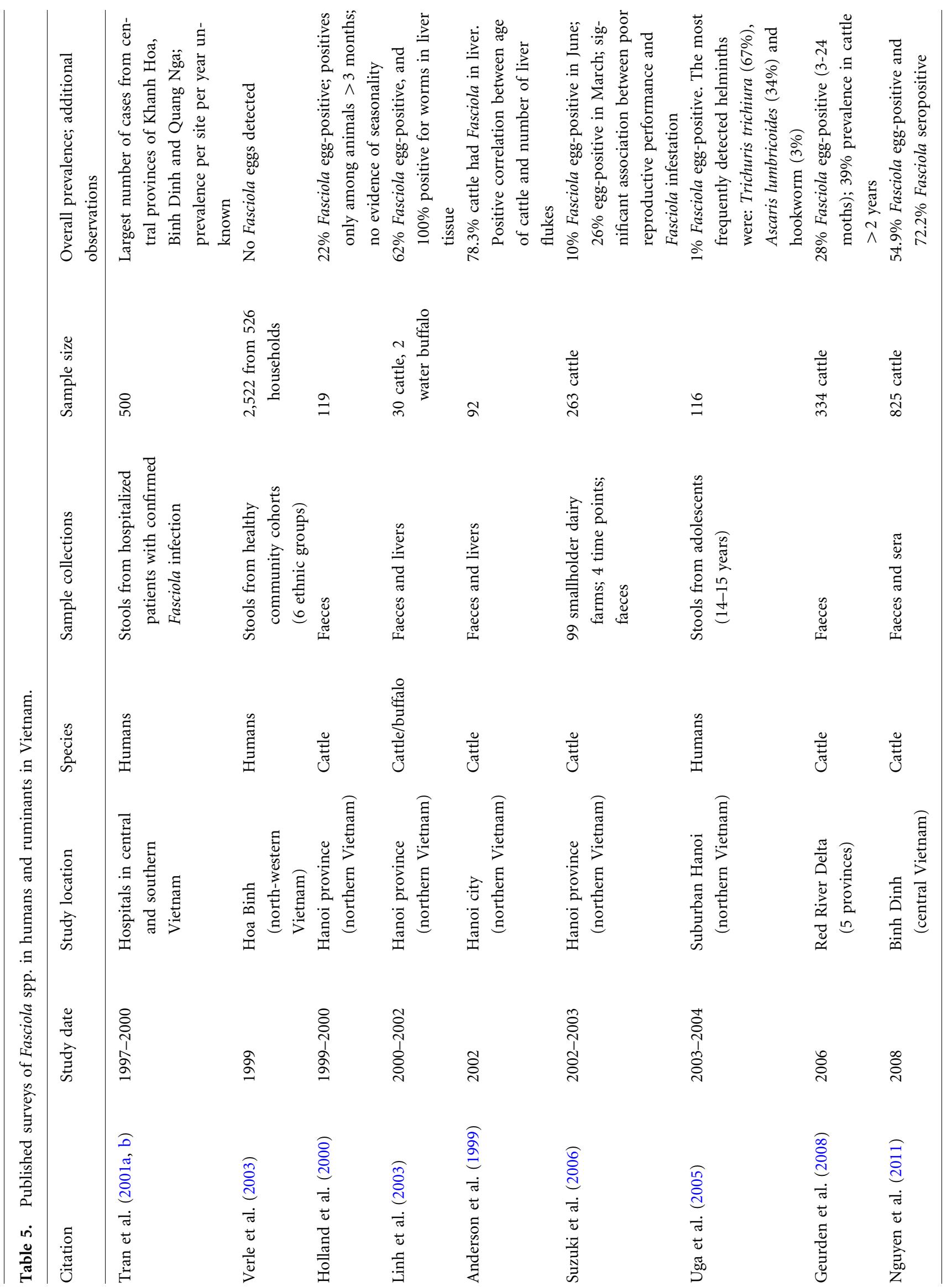




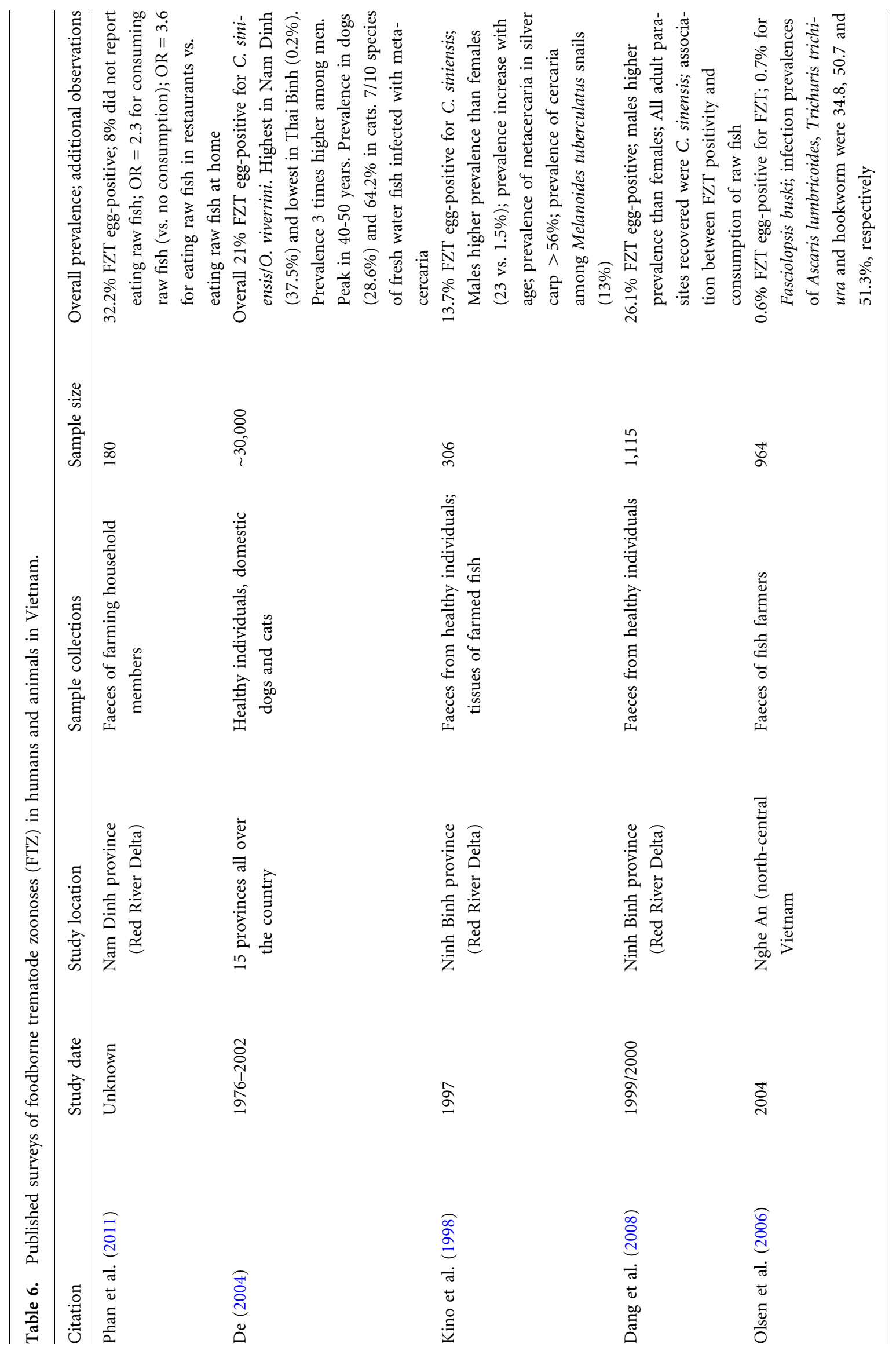




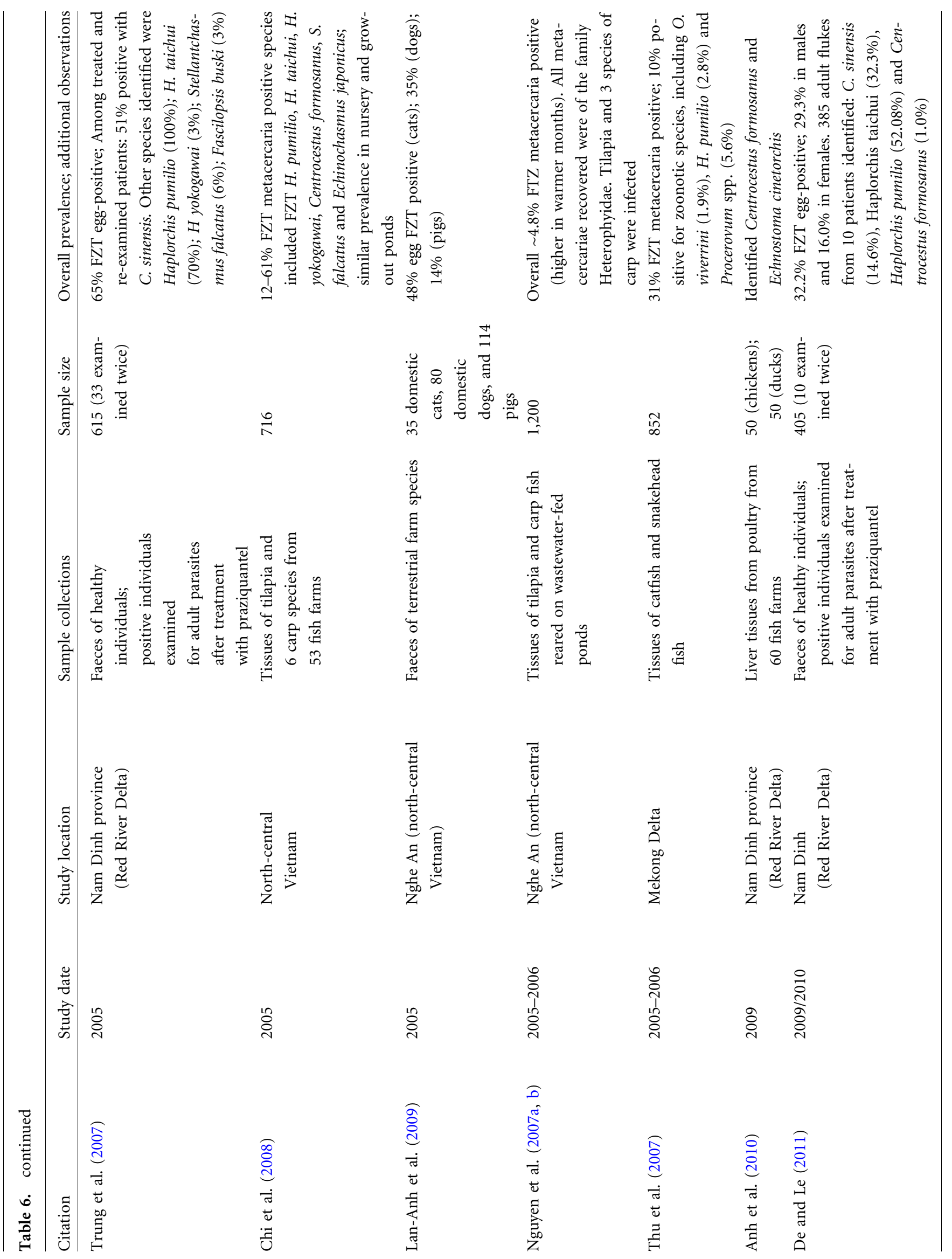




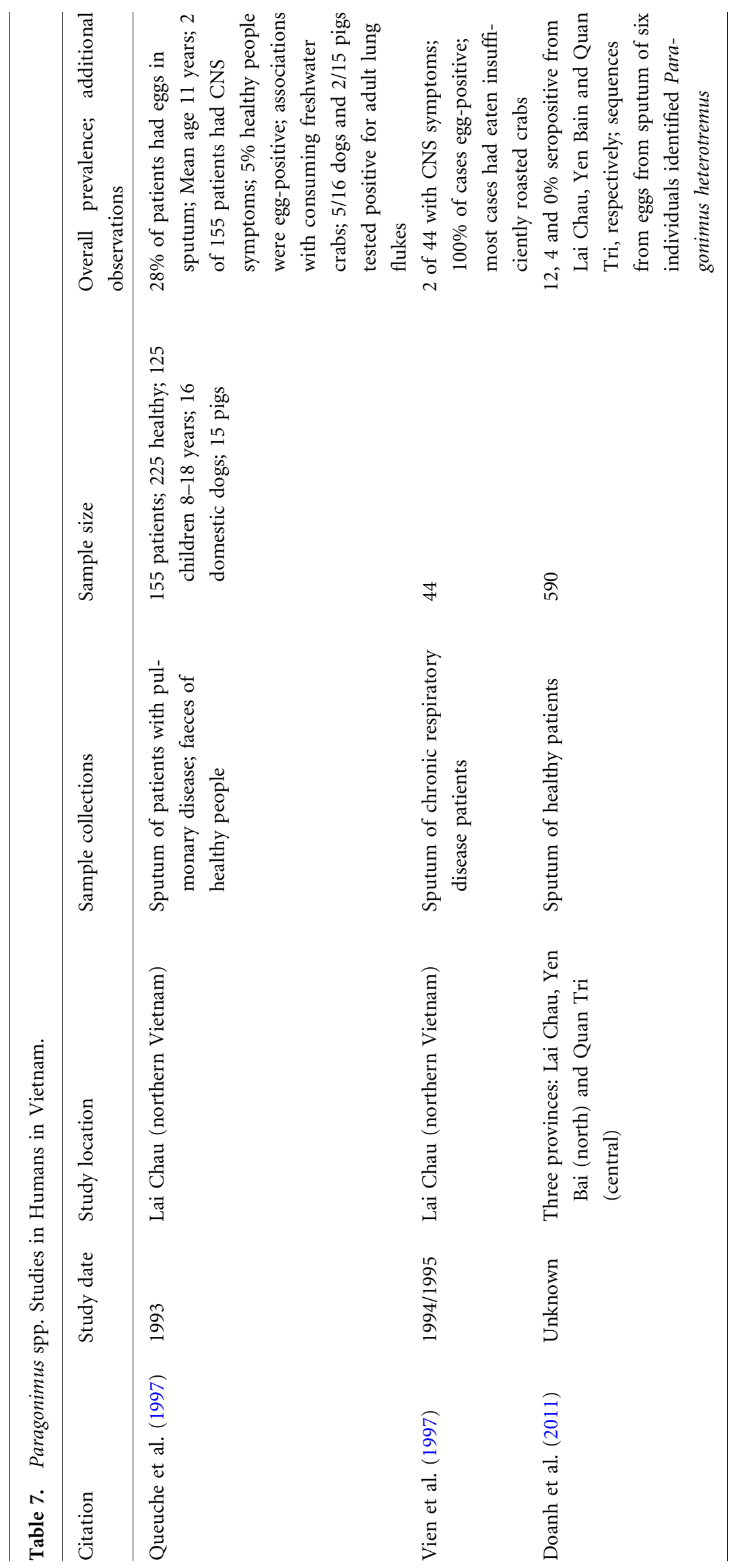


visceral manifestations (Xuan et al. 2004). Severe eye infection due to G. spinigerum was reported in the Mekong Delta (Xuan le et al. 2002). Market surveys of eels ( $n=1,081)$ in HCMC identified G. spinigerum AL3 in 0.11\% (Le and Rojekittikhun 2000). Prevalence was higher in wild-caught eels and at the end of the rainy season (Sieu et al. 2009).

\section{Other FBZ Reported in the Vietnamese Literature}

Between 2006 and 2011, 413 human cases and three anthrax deaths were reported in northern Vietnam. All had a history of slaughtering/eating dead ruminants (Tran and Pham 2012). Studies on suspect cases of Toxocara canis using serology confirmed 83 visceral and 33 ocular infections (Tran et al. 2001a; Le et al. 2012). A 2004 serological study of 1,201 dairy cattle in HCMC reported negative results for M. bovis (ELISA) and Brucella spp. (Nguyen et al. 2006).

\section{Discussion}

Our review of 95 publications reveals the highly diverse range of endemic pathogens associated with FBZ in Vietnam. Although a systematic ranking of disease burden associated with FBZ is not possible at this time, the pathogens fall largely into three groups: (1) pathogens that are relatively more common as causes of clinical disease in Vietnam than in developed temperate-zone countries; (2) pathogens known to be present in Vietnam that are not responsible for a particularly high disease burden; and (3) FBZ which may be fairly common, but for which the dearth of either research or surveillance data in Vietnam prohibits making any valid assessments of relative burden.

In the interest of maximizing development impacts and pursuing a One Health research agenda, there are clear imperatives to prioritize research on zoonoses within group 1 that also cause significant production losses and incur the highest economic costs to farmers. We suggest that Streptococcus suis, Leptospira, Fasciola and fish-borne trematode infections meet these criteria, and that a better understanding of the transmission ecology of these pathogens within smallholder production systems could readily generate improved control options with benefits to both human and animal health. In contrast, Campylobacter and NTS belong to the second category of FBZ, for which the clinical disease does not appear to rank particularly high; although elsewhere in the world Campylobacter and NTS are dominant causes of foodborne diarrhoea, and are the focus of intense multinational control efforts. The influence of human-animal contact rates and human population immunity to Campylobacter and NTS merits further research, since future changing patterns of exposure may drive a shift in the age-related incidence of infection. Unfortunately, the majority of pathogens fall within category 3 , for which data sources are entirely inadequate to estimate burden.

Potential impacts of ongoing urbanization and economic development on FBZ in Vietnam are summarized in Table 8 , alongside suggested areas for further research and improved surveillance. Surveillance of FBZ remains one of the weakest aspects of the health systems in Vietnam. In most cases, hospitals do not carry out routine diagnosis of most bacterial and parasitic FBZ. Serious diseases such as leptospirosisa and toxoplasmosis are often not adequately diagnosed and reported.

The pace of industrialization of Vietnam's farming systems varies by sector and region. The trend is towards increasing farm sizes with higher stocking densities and modern management (all-in all-out systems, synchronized breeding, etc.). In the last decade, central decisions made at the Ministry of Agriculture and Rural Development and the Department of Livestock Production to promote restructuring of the poultry sector was viewed as a way to improve control of highly pathogenic avian influenza (HPAI). Although consolidation undoubtedly provides many more opportunities for increased biosecurity at the farm level, it may also increase vulnerabilities to dissemination of pathogens across the food chain. Changes in pathogen exposure, increased stress and breed and management factors may alter herd/flock immunity and pathogen population dynamics. The risk of pathogen emergence in modern versus traditional production systems has received some attention, but largely in relation to viruses (Drew 2011; Graham et al. 2008). It remains to be seen whether knowledge gained on drivers of viral emergence can be generalized to bacterial and parasitic FBZ.

In spite of government efforts to promote consolidation, smallholder mixed crop-livestock production remains dominant in Vietnam. Use of animal/human excreta and feed leftovers is common, especially within the 'VAC system' $($ Vuon $=$ garden, Ao $=$ pond and Chuong $=$ pig pen $)$ (Pham Duc et al. 2011). Such integrated systems provide efficient nutrient recycling, but also may promote transmission of parasites whose life cycles involve invertebrates. 


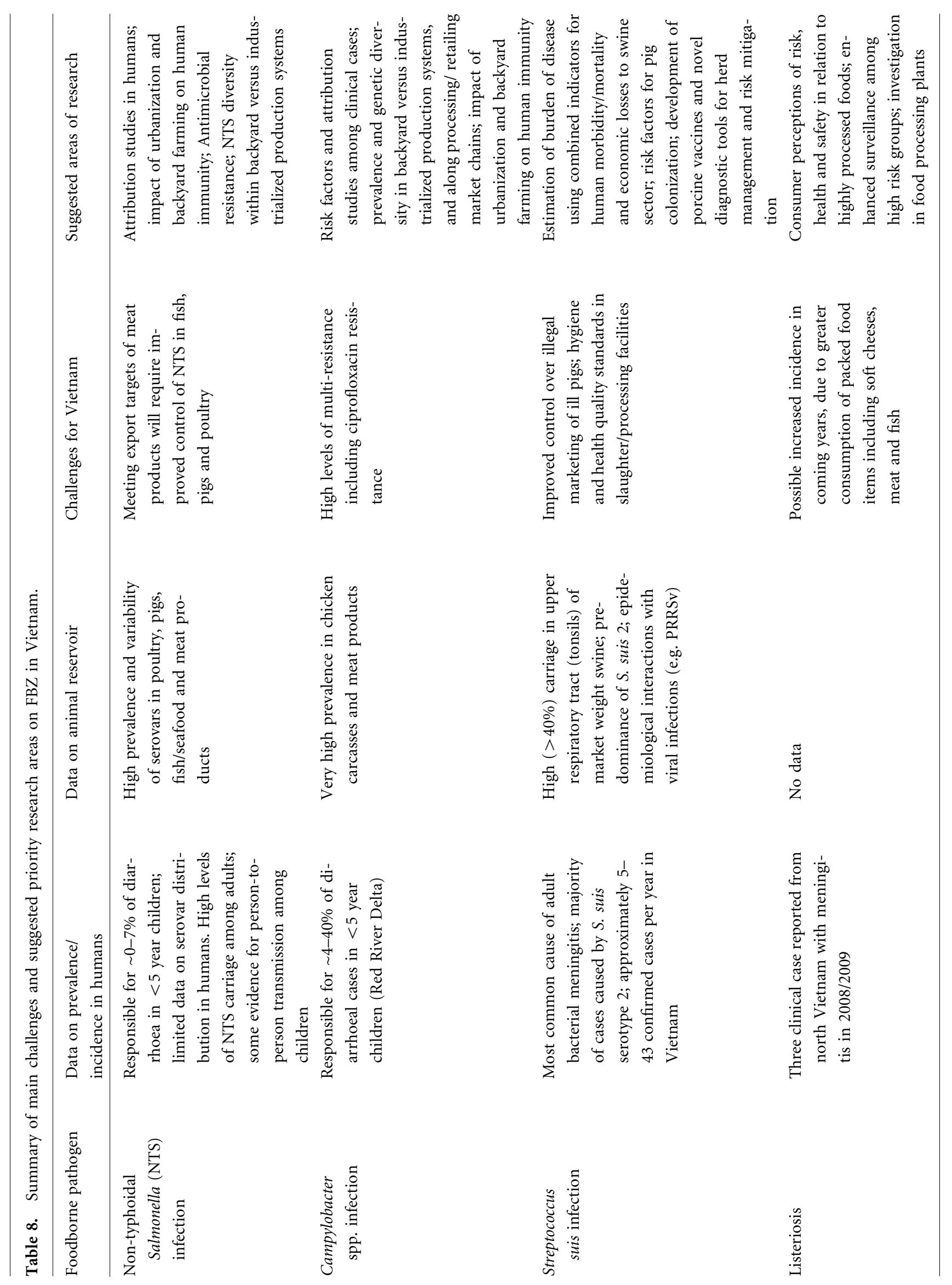




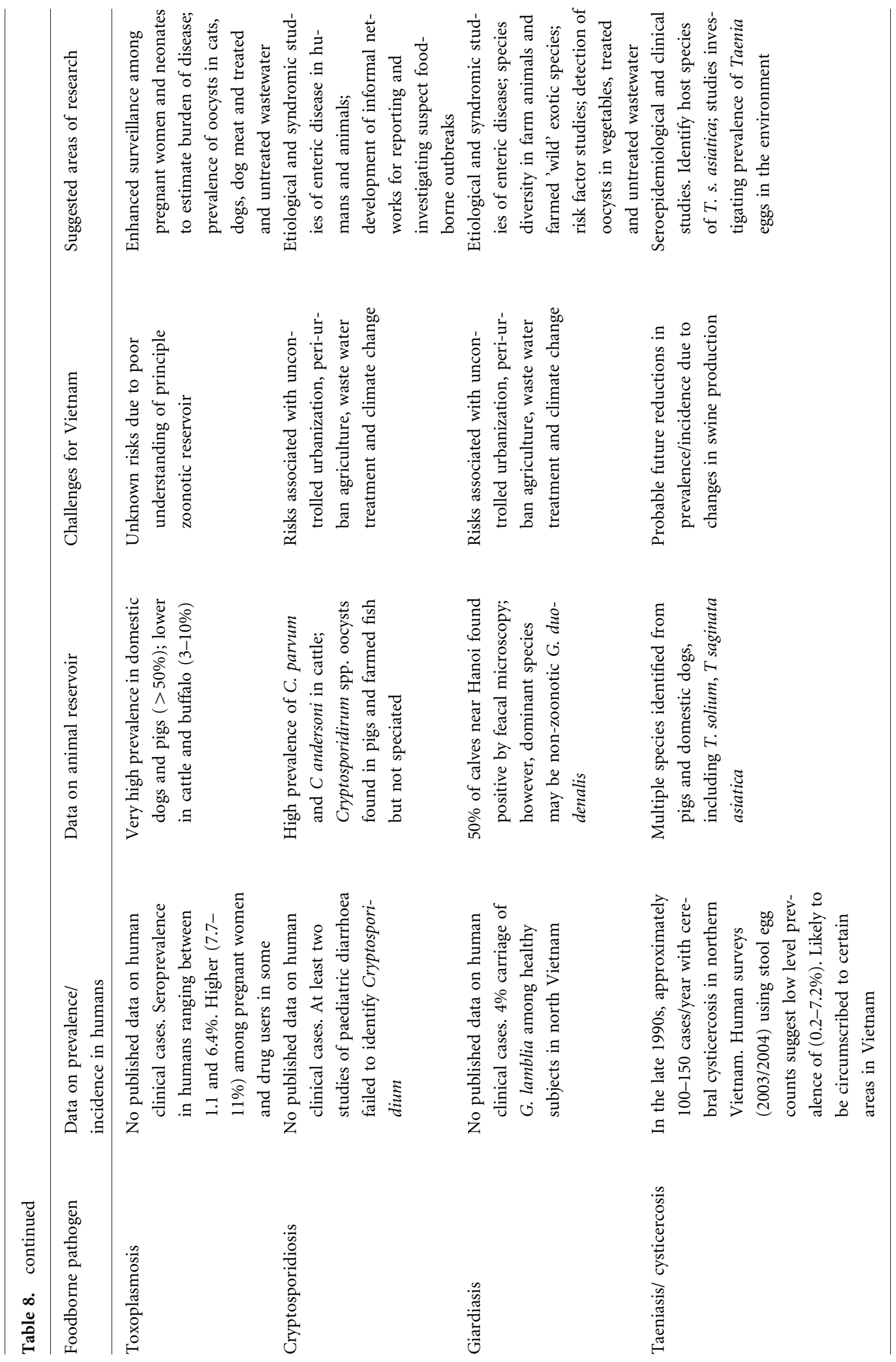




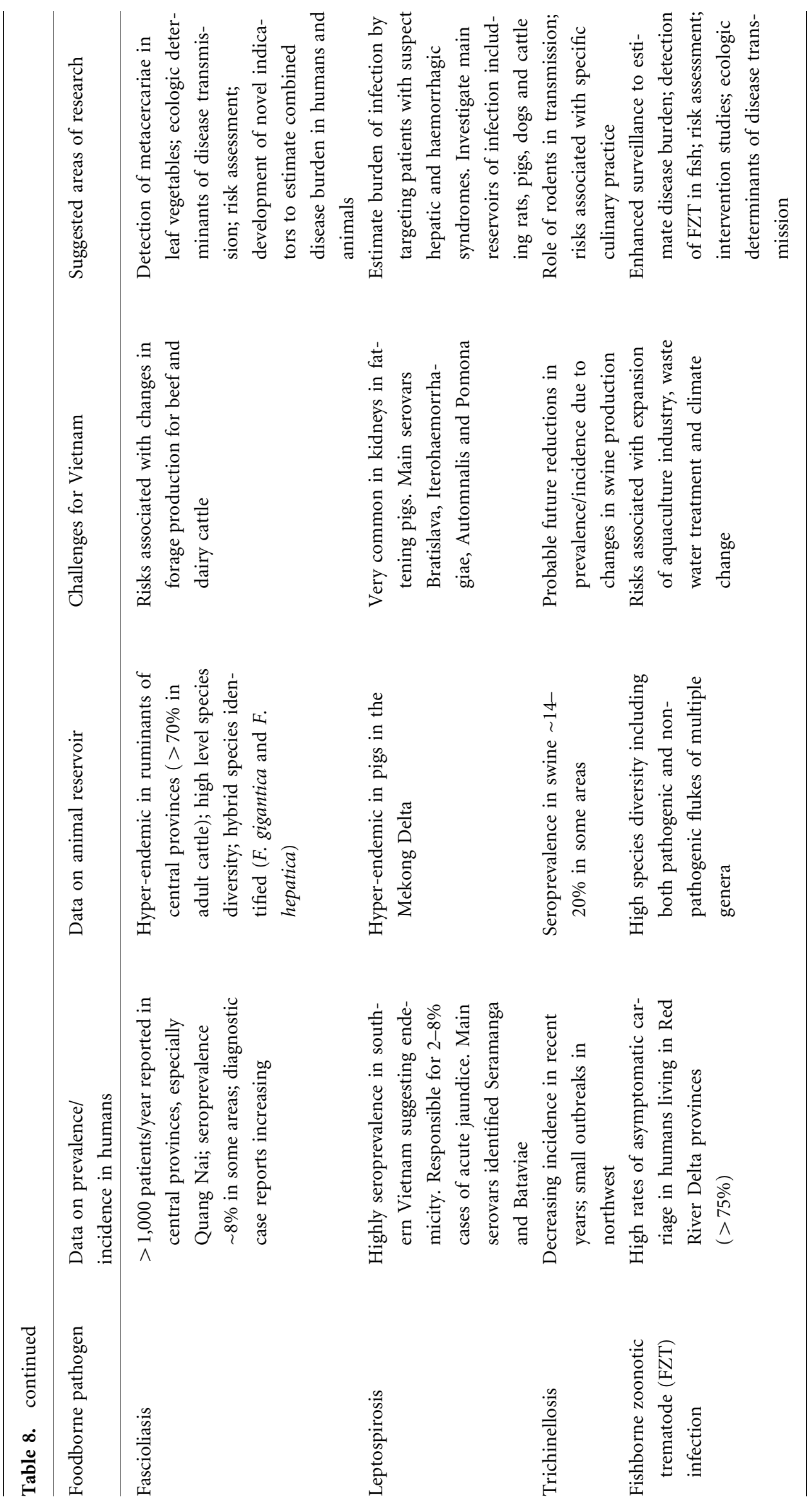


VAC systems are now less common in Vietnam than a few decades ago, due to alternatives for use of animal excreta (i.e. biogas) as well as increasing constraints on land use and increased land costs. Government programmes and development projects aimed at improving sanitation have resulted in safer human waste disposal. Where human excreta are used as fertilizer, a minimum of 6-month retention period is recommended to ensure pathogen inactivation. The level of compliance with this norm is not known, although some data suggests good adherence (Phuc et al. 2006). VAC systems are of course particularly vulnerable to fish-borne trematode infections, whereas industrial aquaculture operations provide increased investments in infrastructure for both quality and safety control, through the use of commercial laboratories for pathogen screening and chemical pest control of invertebrates. In the swine sector, investments in housing and improved nutrition are expected to reduce the burden of parasitic diseases such as taeniasis/cysticercosis and trichinellosis. Intensified bovine and dairy production may increase the risk of introducing cattle-associated FBZ such as bovine tuberculosis and brucellosis. Finally, for target organisms that are particularly associated with processed animal foods, such as listeriosis, increased consumption of processed food items such as soft cheeses, sausages and pates may result in increased incidence unless production of these commodities is adequately regulated.

In Vietnam, per capita ingestion of animal protein has steadily increased over the last few years (Thang and Popkin 2004) and in urban areas, the consumption of chilled, frozen and processed meat is rapidly increasing (Anon. 2011). Modern retail outlets (supermarkets, convenience stores, etc.) now account for $>15 \%$ of total food distribution (Cadilhon et al. 2006), and fast-food restaurants are rapidly proliferating. Consumption of wild-animal meat has also been increasing among wealthy sectors of the population; these 'exotic' products pose novel and unforeseen food safety risks (Drury 2011).

In the past, regulation of food safety in Vietnam has been hampered by highly decentralized authority for monitoring value chains. A Food Safety Law (No. 55/ QH12/2010) seeks to impact quality control of slaughter and processing facilities within food distribution networks, in part through clarifying new standards and regulatory policies. Examples include the development of certification systems for good food production and slaughtering practices, increase traceability and strengthening of penalties for marketing uncertified animals. Better control of food chains is likely to improve control of diseases associated with unregulated marketing (i.e. S. suis). In addition, measures such as zoning regulations on the proximity of production units close to open waterways or urban centres have been introduced. Although the impetus for many of these reforms is driven by the threat of avian influenza pandemics, the measures will likely have an impact both on disease transmission and cultural practices. Efforts to expand export markets of agricultural commodities are also providing an incentive to improve quality controls and laboratory testing; these developments are likely to be driven by the private sector and will target organisms such as NTS to meet international regulatory standards.

In summary, the rapid intensification of animal food production systems and urbanization in Vietnam will undoubtedly change the landscape of food safety risks, introducing both new opportunities for control and prevention, as well as new vulnerabilities for the spread of disease. Within this context, the key for understanding and monitoring changes will be a strengthened infrastructure for surveillance, both of human clinical disease and within the veterinary community.

\section{ACKNOWLEDGMENTS}

The authors want to express their gratitude to Ms Dong Thi Thanh Trang for helping with the translation of Vietnamese journal articles. Work has been co-funded by ZoNMW/ WOTRO (The Netherlands), VIBRE Project (No. 205100012) and the Vietnam Initiative on Zoonotic Infections (VIZIONS), part of the Wellcome Trust Major Overseas Programme (UK).

\section{OPEN ACCESS}

This article is distributed under the terms of the Creative Commons Attribution License which permits any use, distribution, and reproduction in any medium, provided the original author(s) and the source are credited.

\section{REFERENCES}

Adler B, de la Pena Moctezuma A (2010) Leptospira and leptospirosis. Veterinary Microbiology 140:287-296

Anderson N, Luong TT, Vo NG, Bui KL, Smooker PM, Spithill TW (1999) The sensitivity and specificity of two methods for detecting Fasciola infections in cattle. Veterinary Parasitology 83:15-24 
Anh NT, Madsen H, Dalsgaard A, Phuong NT, Thanh DT, Murrell KD (2010) Poultry as reservoir hosts for fishborne zoonotic trematodes in Vietnamese fish farms. Veterinary Parasitology 169:391-394

Anonymous (2011) Packaged Food in Vietnam. International Markets Bureau. Agriculture and Agri-Food, Government of Canada. http://ats.agr.gc.ca/ase/5822-eng.htm. Accessed January 10, 2013.

Ashrafi K, Valero MA, Massoud J, Sobhani A, Solaymani-Mohammadi S, Conde P, et al. (2006) Plant-borne human contamination by fascioliasis. American Journal of Tropical Medicine and Hygiene 75:295-302

Beleneva I (2011) Incidence and characteristics of Staphylococcus aureus and Listeria monocytogenes from the Japan and South China seas. Marine Pollution Bulletin 62:382-387

Bodhidatta L, Lan NT, Hien BT, Lai NV, Srijan A, Serichantalergs O, et al. (2007) Rotavirus disease in young children from Hanoi, Vietnam. The Pediatric Infectious Disease Journal 26:325-328

Boqvist S, Chau BL, Gunnarsson A, Engvall EO, Vagsholm I, Magnusson U (2002) Animal- and herd-level risk factors for leptospiral seropositivity among sows in the Mekong Delta, Vietnam. Preventive Veterinary Medicine 53:233-245

Boqvist S, Thu HTV, Vagsholm I, Magnusson U (2002) The impact of Leptospira seropositivity on reproductive performance in sows in southern Viet Nam. Theriogenology 58:1327-1335

Cadilhon J, Moustier N, Poole N, Tam P, Fearne P (2006) Traditional vs. modern food systems? Insights from vegetable supply chains to Ho Chi Minh City (Vietnam) Development Policy Review 24:31-49

Chai JY, Darwin Murrell K, Lymbery AJ (2005) Fish-borne parasitic zoonoses: status and issues. International Journal for Parasitology 35:1233-1254

Chau TT, Campbell JI, Schultsz C, Chau NV, Diep TS, Baker S, et al. (2010) Three adult cases of Listeria monocytogenes meningitis in Vietnam. PLoS Medicine 7:e1000306

Chau TTH, Campbell J, Schultsz C, Nguyen C, To D, Baker S, et al. (2010) Three adult cases of Listeria monocytogenes meningitis in Vietnam. PLoS Medicine 7:e1000306

Chen Y, Guo Y, Wang Z, Liu X, Liu H, Dai Y, et al. (2010) Foodborne disease outbreaks in 2006 report of the National Foodborne Disease Surveillance Network, China. Wei Sheng Yan Jiu 39:331-334

Chi TT, Dalsgaard A, Turnbull JF, Tuan PA, Murrell KD (2008) Prevalence of zoonotic trematodes in fish from a Vietnamese fish-farming community. Journal of Parasitology 94:423-428

Choi D, Lim JH, Lee KT, Lee JK, Choi SH, Heo JS, et al. (2006) Cholangiocarcinoma and Clonorchis sinensis infection: a casecontrol study in Korea. Journal of Hepatology 44:1066-1073

Clinton White J (2010) Cryptosporidium species. In: Principle and Practice of Infectious Diseases, Mandell G, Bennet J, Dolin R (editors), Philadelphia: Churchill Livingstone/Elsevier, pp 3547-3586

Coker RJ, Hunter BM, Rudge JW, Liverani M, Hanvoravongchai P (2011) Health in Southeast Asia 3. Emerging infectious diseases in southeast Asia: regional challenges to control. Lancet 377:599-609

Conlan JV, Vongxay K, Fenwick S, Blacksell SD, Thompson RC (2009) Does interspecific competition have a moderating effect on Taenia solium transmission dynamics in Southeast Asia? Trends in Parasitology 25:398-403

Dang TC, Yajima A, Nguyen VK, Montresor A (2008) Prevalence, intensity and risk factors for clonorchiasis and possible use of questionnaires to detect individuals at risk in northern Vietnam. Transactions of the Royal Society of Tropical Medicine and Hygiene 102:1263-1268

De NV (2004) Fish-borne trematodes in Vietnam. Southeast Asian Journal of Tropical Medicine and Public Health 35:299-301

De NV, Le TH (2011) Human infections of fish-borne trematodes in Vietnam: prevalence and molecular specific identification at an endemic commune in Nam Dinh province. Experimental Parasitology 129:355-361

De NV, Murrell KD, Cong LD, Cam PD, Chau LV, Toan ND, et al. (2003) The food-borne trematode zoonoses of Vietnam. The Southeast Asian Journal of Tropical Medicine and Public Health 34(Suppl 1):12-34

Do TT, Bui TT, Molbak K, Phung DC, Dalsgaard A (2007) Epidemiology and aetiology of diarrhoeal diseases in adults engaged in wastewater-fed agriculture and aquaculture in Hanoi, Vietnam. Tropical Medicine \& International Health 12(Suppl 2):23-33

Doanh PN, Shinohara A, Horii Y, Habe S, Nawa Y, Le NT (2007) Description of a new lung fluke species, Paragonimus vietnamensis sp. nov. (Trematoda, Paragonimidae), found in northern Vietnam. Parasitology Research 101:1495-1501

Doanh PN, Shinohara A, Horii Y, Habe S, Nawa Y, Le NT (2008) Discovery of Paragonimus proliferus in Northern Vietnam and their molecular phylogenetic status among genus Paragonimus. Parasitology Research 102:677-683

Doanh PN, Shinohara A, Horii Y, Habe S, Nawa Y (2009) Discovery of Paragonimus westermani in Vietnam and its molecular phylogenetic status in $P$. westermani complex. Parasitology Research 104:1149-1155

Doanh PN, Dung do T, Thach DT, Horii Y, Shinohara A, Nawa Y (2011) Human paragonimiasis in Viet Nam: epidemiological survey and identification of the responsible species by DNA sequencing of eggs in patients' sputum. Parasitology International 60:534-537

Dorny P, Somers R, Cam Thi Dang T, Khong Nguyen V, Vercruysse J (2004) Cysticercosis in Cambodia, Lao PDR and Vietnam. Southeast Asian Journal of Tropical Medicine and Public Health 35:223-226

Dorny P, Somers R, Vercruysse J (2007) Response to comment on: Human tapeworms in north Vietnam. Transactions of the Royal Society of Tropical Medicine and Hygiene 101:629-630

Drew TW (2011) The emergence and evolution of swine viral diseases: to what extent have husbandry systems and global trade contributed to their distribution and diversity? Revue Scientifique et Technique 30:95-106

Drury R (2011) Hungry for success: urban consumer demand for wild animal products in Vietnam. Conservation and Society 9:247-257

Dubey JP, Huong LT, Sundar N, Su C (2007) Genetic characterization of Toxoplasma gondii isolates in dogs from Vietnam suggests their South American origin. Veterinary Parasitology 146:347-351

Dubey JP, Huong LT, Lawson BW, Subekti DT, Tassi P, Cabaj W, et al. (2008) Seroprevalence and isolation of Toxoplasma gondii from free-range chickens in Ghana, Indonesia, Italy, Poland, and Vietnam. Journal of Parasitology 94:68-71

Dyar OJ, Hoa NQ, Trung NV, Phuc HD, Larsson M, Chuc NT, et al. (2012) High prevalence of antibiotic resistance in commensal Escherichia coli among children in rural Vietnam. BMC Infectious Diseases 12:92 
EFSA (2012) The European Union summary report on trends and sources of zoonoses, zoonotic agents and food-borne outbreaks in 2010. EFSA Journal 10:2597

Ellerbroek L, Narapati D, Tai NP, Poosaran N, Pinthong R, Sirimalaisuwan A, et al. (2010) Antibiotic resistance in Salmonella isolates from imported chicken carcasses in Bhutan and from pig carcasses in Vietnam. Journal of Food Protection 73:376-379

Erhart A, Dorny P, Van De N, Vien HV, Thach DC, Toan ND, et al. (2002) Taenia solium cysticercosis in a village in northern Viet Nam: seroprevalence study using an ELISA for detecting circulating antigen. Transactions of the Royal Society of Tropical Medicine and Hygiene 96:270-272

Fayer R (2004) Cryptosporidium: a water-borne zoonotic parasite. Veterinary Parasitology 126:37-56

Galan-Puchades MT, Fuentes MV (2009) Diagnosis of human cysticercosis and Taenia asiatica. American Journal of Tropical Medicine and Hygiene 81:1165 (author reply 1166)

Garin B, Gouali M, Wouafo M, Perchec AM, Thu PM, Ravaonindrina N, et al. (2012) Prevalence, quantification and antimicrobial resistance of Campylobacter spp. on chicken neck-skins at points of slaughter in 5 major cities located on 4 continents. International Journal of Food Microbiology 157:102-107

Geurden T, Somers R, Thanh NT, Vien LV, Nga VT, Giang HH, et al. (2008) Parasitic infections in dairy cattle around Hanoi, northern Vietnam. Veterinary Parasitology 153:384-388

Gibson-Kueh S, Yang R, Thuy NT, Jones JB, Nicholls PK, Ryan U (2011) The molecular characterization of an Eimeria and Cryptosporidium detected in Asian seabass (Lates calcarifer) cultured in Vietnam. Veterinary Parasitology 181:91-96

Graham JP, Leibler JH, Price LB, Otte JM, Pfeiffer DU, Tiensin T, et al. (2008) The animal-human interface and infectious disease in industrial food animal production: rethinking biosecurity and biocontainment. Public Health Reports 123:282-299

Ha TA, Pham TY (2006) Study of Salmonella, Campylobacter, and Escherichia coli contamination in raw food available in factories, schools, and hospital canteens in Hanoi, Vietnam. Annals of the New York Academy of Sciences 1081:262-265

Hall G, Kirk MD, Becker N, Gregory JE, Unicomb L, Millard G, et al. (2005) Estimating foodborne gastroenteritis, Australia. Emerging Infectious Diseases 11:1257-1264

Hedegaard Clausen J, Madsen H, Murrell KD, Van PT, Thu HN, Do DT, et al. (2012) Prevention and control of fish-borne zoonotic trematodes in fish nurseries, Vietnam. Emerging Infectious Diseases 18:1438-1445

Hien BT, Trang do T, Scheutz F, Cam PD, Molbak K, Dalsgaard A (2007) Diarrhoeagenic Escherichia coli and other causes of childhood diarrhoea: a case-control study in children living in a wastewater-use area in Hanoi, Vietnam. Journal of Medical Microbiology 56:1086-1096

Ho Dang Trung N, Le Thi Phuong T, Wolbers M, Nguyen Van Minh H, Nguyen Thanh V, Van MP, et al. (2012) Aetiologies of central nervous system infection in Viet Nam: a prospective provincial hospital-based descriptive surveillance study. PLoS ONE 7:e37825

Hoa NT, Chieu TTB, Dung SD, Long NT, Quoc T, Hieu TQ, et al. (2013) S. suis serotype 2 and PRRSV in pigs, Vietnam 2010. Emerging Infectious Diseases 19:331-333

Holland WG, Luong TT, Nguyen LA, Do TT, Vercruysse J (2000) The epidemiology of nematode and fluke infections in cattle in the Red River Delta in Vietnam. Veterinary Parasitology 93:141147
Hong TTT, Linh NQ, Ogle B, Lindberg JE (2006) Survey on the prevalence of diarrhoea in pre-weaning piglets and on feeding systems as contributing risk factors in smallholdings in central Vietnam. Tropical Animal Health and Production 38:397-405

HPA (2013) Table of Zoonotic Diseases and Organisms. http://www.hpa.org.uk/Topics/InfectiousDiseases/InfectionsAZ/ Zoonoses/TableZoonoticDiseases. Accessed March 12, 2012.

Hubalek Z (2003) Emerging human infectious diseases: anthroponoses, zoonoses, and sapronoses. Emerging Infectious Diseases 9:403-404

Huong LT, Dubey JP (2007) Seroprevalence of Toxoplasma gondii in pigs from Vietnam. Journal of Parasitology 93:951-952

Huong LT, Ljungstrom BL, Uggla A, Bjorkman C (1998) Prevalence of antibodies to Neospora caninum and Toxoplasma gondii in cattle and water buffaloes in southern Vietnam. Veterinary Parasitology 75:53-57

Indrawattana N, Nibaddhasobon $\mathrm{T}$, Sookrung $\mathrm{N}$, Chongsa-Nguan M, Tungtrongchitr A, Makino S, et al. (2011) Prevalence of Listeria monocytogenes in raw meats marketed in Bangkok and characterization of the isolates by phenotypic and molecular methods. Journal of Health, Population and Nutrition 29:26-38

Isenbarger D, Hien B, Ha H, Ha T, Bodhidatta L, Pang L, et al. (2001) Prospective study of the incidence of diarrhoea and prevalence of bacterial pathogens in a cohort of Vietnamese children along the Red River. Epidemiology and Infection 127:229-236

Jenkins MB, Liotta JL, Lucio-Forster A, Bowman DD (2010) Concentrations, viability, and distribution of Cryptosporidium genotypes in lagoons of swine facilities in the Southern Piedmont and in coastal plain watersheds of Georgia. Applied and Environment Microbiology 76:5757-5763

Jittapalapong S, Nimsupan B, Pinyopanuwat N, Chimnoi W, Kabeya H, Maruyama S (2007) Seroprevalence of Toxoplasma gondii antibodies in stray cats and dogs in the Bangkok metropolitan area, Thailand. Veterinary Parasitology 145:138141

Khan MI, Ochiai RL, von Seidlein L, Dong B, Bhattacharya SK, Agtini MD, et al. (2010) Non-typhoidal Salmonella rates in febrile children at sites in five Asian countries. Tropical Medicine \& International Health 15:960-963

Kino H, Inaba H, Van De N, Van Chau L, Son DT, Hao HT, et al. (1998) Epidemiology of clonorchiasis in Ninh Binh Province, Vietnam. Southeast Asian Journal of Tropical Medicine and Public Health 29:250-254

Ky H, Van Chap N (2000) Radioclinical aspects of cerebral and muscular cysticercosis: 20 cases. Journal of Neuroradiology 27:264-266

Lan-Anh NT, Phuong NT, Murrell KD, Johansen MV, Dalsgaard A, Thu LT, et al. (2009) Animal reservoir hosts and fish-borne zoonotic trematode infections on fish farms, Vietnam. Emerging Infectious Diseases 15:540-546

Laras K, Van CB, Bounlu K, Tien NTK, Olson JG, Thongchanh S, et al. (2002) The importance of leptospirosis in Southeast Asia. American Journal of Tropical Medicine and Hygiene 67:278-286

Le Bas C, Tran TH, Nguyen TT, Dang DT, Ngo CT (2006) Prevalence and epidemiology of Salmonella spp. in small pig abattoirs of Hanoi, Vietnam. Annals of the New York Academy of Sciences 1081:269-272

Le TX, Rojekittikhun W (2000) A survey of infective larvae of Gnathostoma in eels sold in Ho Chi Minh City. Southeast Asian Journal of Tropical Medicine and Public Health 31:133-137 
le Xuan T, Rojekittikhun W, Punpoowong B, le Trang N, Hien TV (2002) Case report: intraocular gnathostomiasis in Vietnam. Southeast Asian Journal of Tropical Medicine and Public Health 33:485-489

Le TH, De NV, Agatsuma T, Blair D, Vercruysse J, Dorny P, et al. (2007) Molecular confirmation that Fasciola gigantica can undertake aberrant migrations in human hosts. Journal of Clinical Microbiology 45:648-650

Le TH, De NV, Agatsuma T, Thi Nguyen TG, Nguyen QD, McManus DP, et al. (2008) Human fascioliasis and the presence of hybrid/introgressed forms of Fasciola hepatica and Fasciola gigantica in Vietnam. International Journal for Parasitology $38: 725-730$

Le A, Pham MH, Le TH (2012) Mot so dac diem dich te hoc nhiem Toxocara tren benh nhan may day man tinh nhiem Toxocara tai Vien 103. Tạp chì phòng chống bệnh sốt rét và các bệnh ký sinh trùng 52-58.

Lestari ES, Severin JA, Verbrugh HA (2012) Antimicrobial resistance among pathogenic bacteria in Southeast Asia. Southeast Asian Journal of Tropical Medicine and Public Health 43:385-422

Linh BK, Thuy DT, My LN, Sasaki O, Yoshihara S (2003) Application of agar gel diffusion test to the diagnosis of fasciolosis in cattle and buffaloes in the Red River Delta of Vietnam. Japan Agricultural Research Quarterly 37:201-205

Liu X, Chen Y, Wang X, Ji R (2004) Foodborne disease outbreaks in China from 1992 to 2001 national foodborne disease surveillance system. Wei Sheng Yan Jiu 33:725-727

Liu XM, Chen Y, Fan YX, Wang MQ (2006) Foodborne diseases occurred in 2003-report of the National Foodborne Diseases Surveillance System, China. Wei Sheng Yan Jiu 35:201-204

Luu QH, Tran TH, Phung DC, Nguyen TB (2006) Study on the prevalence of Campylobacter spp. from chicken meat in Hanoi, Vietnam. Annals of the New York Academy of Sciences 1081:273-275

Mai NT, Hoa NT, Nga TV, le Linh D, Chau TT, Sinh DX, et al. (2008) Streptococcus suis meningitis in adults in Vietnam. Clinical Infectious Diseases 46:659-667

Mas-Coma S (2005) Epidemiology of fascioliasis in human endemic areas. Journal of Helminthology 79:207-216

Mayer DA, Fried B (2007) The role of helminth infections in carcinogenesis. Advances in Parasitology 65:239-296

Montoya J, Boothroyd J, Kovacs J (2010) Toxoplasma gondii. In: Principle and Practice of Infectious Diseases, Mandell G, Bennet J, Dolin R (editors), Philadelphia: Churchill Livingstone/Elsevier, pp 3495-3526

Nga TV, Parry CM, Le T, Lan NP, Diep TS, Campbell JI, et al. (2012) The decline of typhoid and the rise of non-typhoid salmonellae and fungal infections in a changing HIV landscape: bloodstream infection trends over 15 years in southern Vietnam. Transactions of the Royal Society of Tropical Medicine and Hygiene 106:26-34

Ngan PK, Khanh NG, Tuong CV, Quy PP, Anh DN, Thuy HT (1992) Persistent diarrhea in Vietnamese children: a preliminary report. Acta Paediatrica 81(Suppl 381):124-126

Nghia HD, Hoa NT, le Linh D, Campbell J, Diep TS, Chau NV, et al. (2008) Human case of Streptococcus suis serotype 16 infection. Emerging Infectious Diseases 14:155-157

Nghia HD, le Tu TP, Wolbers M, Thai CQ, Hoang NV, Nga TV, et al. (2011) Risk factors of Streptococcus suis infection in Vietnam. A case-control study. PLoS ONE 6:e17604

Ngo TH, T TBC, Tran TTN, Nguyen VD, Campbell J, Pham HA, et al. (2011) Slaughterhouse pigs are a major reservoir of
Streptococcus suis Serotype 2 capable of causing human infection in southern Vietnam. PLoS ONE 6:e17943

Nguyen TV, Le Van P, Le Huy C, Weintraub A (2004) Diarrhea caused by rotavirus in children less than 5 years of age in Hanoi, Vietnam. Journal of Clinical Microbiology 42:5745-5750

Nguyen D, Le P, Huyn L, Truong C (2006) Dieu tra tinh hinh nhiem vi khuan va phan tich cac yeu to lien quan voi mot so benh vi khuan lay sang nguoi tren dan bo sua tai tp. Ho Chi Minh. Khoa hoc kỹ thuạt thú y 13:43-46

Nguyen ST, Nguyen DT, Le DQ, Le Hua LN, Van Nguyen T, Honma H, et al. (2007) Prevalence and first genetic identification of Cryptosporidium spp. in cattle in central Viet Nam. Veterinary Parasitology 150:357-361

Nguyen TH, Nguyen VD, Murrell D, Dalsgaard A (2007) Occurrence and species distribution of fishborne zoonotic trematodes in wastewater-fed aquaculture in northern Vietnam. Tropical Medicine \& International Health 12(Suppl 2):66-72

Nguyen TG, Van De N, Vercruysse J, Dorny P, Le TH (2009) Genotypic characterization and species identification of Fasciola spp. with implications regarding the isolates infecting goats in Vietnam. Experimental Parasitology 123:354-361

Nguyen TG, Le TH, Dao TH, Tran TL, Praet N, Speybroeck N, et al. (2011) Bovine fasciolosis in the human fasciolosis hyperendemic Binh Dinh province in central Vietnam. Acta Tropica 117:19-22

Nguyen ST, Honma H, Geurden T, Ikarash M, Fukuda Y, Huynh VV, et al. (2012) Prevalence and risk factors associated with Cryptosporidium oocysts shedding in pigs in central Vietnam. Research in Veterinary Science 93:848-852

Nissapatorn V, Noor Azmi MA, Cho SM, Fong MY, Init I, Rohela M, et al. (2003) Toxoplasmosis: prevalence and risk factors. Journal of Obstetrics and Gynaecology 23:618-624

Olsen A, le Thuan K, Murrell KD, Dalsgaard A, Johansen MV, De NV (2006) Cross-sectional parasitological survey for helminth infections among fish farmers in Nghe An province, Vietnam. Acta Tropica 100:199-204

Painter JA, Hoekstra RM, Ayers T, Tauxe RV, Braden CR, Angulo FJ, et al. (2013) Attribution of foodborne illnesses, hospitalizations, and deaths to food commodities by using outbreak data, United States, 1998-2008. Emerging Infectious Diseases 19:407-415

Pegues D, Miller SI (2010) Salmonella species, including Salmonella typhi. In: Principle and Practice of Infectious Diseases, Mandell G, Bennet J, Dolin R (editors), Philadelphia: Churchill Livingstone/Elsevier, pp 2887-2903

Pham Duc P, Nguyen-Viet H, Hattendorf J, Zinsstag J, Dac Cam P, Odermatt P (2011) Risk factors for Entamoeba histolytica infection in an agricultural community in Hanam province, Vietnam. Parasites \& Vectors 4:102

Phan TT, Khai LTL, Ogasawara N, Tam NT, Okatani AT, Akiba M, et al. (2005) Contamination of Salmonella in retail meats and shrimps in the Mekong Delta, Vietnam. Journal of Food Protection 68:1077-1080

Phan M, Ersboll A, Do D, Dalsgaard A (2011) Raw-fish-eating behavior and fishborne zoonotic trematode infection in people of northern Vietnam. Foodborne Pathogens and Disease 8:255260

Phuc PD, Konradsen F, Phuong PT, Cam PD, Dalsgaard (2006) Practice of using human excreta as fertilizer and implications for health in Nghe An province, Vietnam. Southeast Asian Journal of Tropical Medicine and Public Health 37:222-229 
Pozio E, Hoberg E, La Rosa G, Zarlenga DS (2009) Molecular taxonomy, phylogeny and biogeography of nematodes belonging to the Trichinella genus. Infection, Genetics and Evolution 9:606-616

Queuche F, Van Cao V, Le Dang H (1997) Endemic area of paragonimiasis in Vietnam. Sante 7:155-159

Sery V, Zastera M, Prokopec J, Radkovsky J, The PH, Canh DT (1988) To the problem of toxoplasmosis in Vietnam. Bulletin of the Institute of Maritime and Tropical Medicine in Gdynia 39:181-185

Sieu TP, Dung TT, Nga NT, Hien TV, Dalsgaard A, Waikagul J, et al. (2009) Prevalence of Gnathostoma spinigerum infection in wild and cultured swamp eels in Vietnam. Journal of Parasitology 95:246-248

Smythe LD, Wuthiekanun V, Chierakul W, Suputtamongkol Y, Tiengrim S, Dohnt MF, et al. (2009) The microscopic agglutination test (MAT) is an unreliable predictor of infecting Leptospira serovar in Thailand. American Journal of Tropical Medicine and Hygiene 81:695-697

Somers R, Dorny P, Nguyen VK, Dang TC, Goddeeris B, Craig PS, et al. (2006) Taenia solium taeniasis and cysticercosis in three communities in north Vietnam. Tropical Medicine \& International Health 11:65-72

Somers R, Dorny P, Geysen D, Nguyen LA, Thach DC, Vercruysse J, et al. (2007) Human tapeworms in north Vietnam. Transactions of the Royal Society of Tropical Medicine and Hygiene 101:275-277

Sotelo J (2003) Neurocysticercosis: eradication of cysticercosis is an attainable goal. British Medical Journal 326:511-512

Suzuki K, Kanameda M, Inui K, Ogawa T, Nguyen VK, Dang TT, et al. (2006) A longitudinal study to identify constraints to dairy cattle health and production in rural smallholder communities in Northern Vietnam. Research in Veterinary Science 81:177-184

Ta YT, Nguyen TT, To PB, da Pham X, Le HT, Alali WQ, et al. (2012) Prevalence of Salmonella on chicken carcasses from retail markets in Vietnam. Journal of Food Protection 75: $1851-1854$

Taira N, Yoshifuji H, Boray JC (1997) Zoonotic potential of infection with Fasciola spp. by consumption of freshly prepared raw liver containing immature flukes. International Journal for Parasitology 27:775-779

Taylor WRJ, Giang VT, Thai QN, Duong VD, Viet KN, Cap TN, et al. (2009) Acute febrile myalgia in Vietnam due to trichinellosis following the consumption of raw pork. Clinical Infectious Diseases 49:E79-E83

Thai KTD, Binh TQ, Giao PT, Phuong HL, Hung LQ, Van Nam $\mathrm{N}$, et al. (2006) Seroepidemiology of leptospirosis in southern Vietnamese children. Tropical Medicine \& International Health 11:738-745

Thai TH, Hirai T, Lan NT, Yamaguchi R (2012) Antibiotic resistance profiles of Salmonella serovars isolated from retail pork and chicken meat in North Vietnam. International Journal of Food Microbiology 156:147-151

Thang NM, Popkin BM (2004) Patterns of food consumption in Vietnam: effects on socioeconomic groups during an era of economic growth. European Journal of Clinical Nutrition $58: 145-153$

Thi NV, Dorny P, La Rosa G, Long TT, Van CN, Pozio E (2010) High prevalence of anti-Trichinella IgG in domestic pigs of the Son La province, Vietnam. Veterinary Parasitology 168:136-140

Thompson CN, Phan VT, Le TP, Pham TN, Hoang LP, Ha V, et al. (2012) Epidemiological features and risk factors of Sal- monella gastroenteritis in children resident in Ho Chi Minh City, Vietnam. Epidemiology \& Infection 141:1604-1613

Thu ND, Dalsgaard A, Loan LT, Murrell KD (2007) Survey for zoonotic liver and intestinal trematode metacercariae in cultured and wild fish in An Giang Province, Vietnam. Korean Journal of Parasitology 45:45-54

Tran D, Pham H (2012). Mot so dac diem dich te hoc benh than o nguoi mien bac Viet Nam, 2006-2011. Tap chí Y học dựphòng 22.

Tran H, Tran KD, Tran H, Le T, Nguyen H (2001) Mot so dac diem trong hoi chung au trung di chuyen noi tang do gium dua cho Toxocara canis. Y Hoc Tp Ho Chi Minh 4:192-197

Tran VH, Tran TK, Nguye HC, Pham HD, Pham TH (2001) Fascioliasis in Vietnam. The Southeast Asian Journal of Tropical Medicine and Public Health 32(Suppl 2):48-50

Tran TP, Ly TL, Nguyen TT, Akiba M, Ogasawara N, Shinoda D, et al. (2004) Prevalence of Salmonella spp. in pigs, chickens and ducks in the Mekong Delta, Vietnam. Journal of Veterinary Medical Science 66:1011-1014

Trung D, Van N, Waikagul J, Dalsgaard A, Chai JY, Sohn WM, et al. (2007) Fishborne zoonotic intestinal trematodes, Vietnam. Emerging Infectious Diseases 13:1828-1833

Udonsom R, Lekkla A, Chung P, Cam P, Sukthana Y (2008) Seroprevalence of Toxoplasma gondii antibody in Vietnamese villagers. Southeast Asian Journal of Tropical Medicine and Public Health 39:14-18

Uga S, Hoa NT, le Thuan K, Noda S, Fujimaki Y (2005) Intestinal parasitic infections in schoolchildren in a suburban area of Hanoi, Vietnam. Southeast Asian Journal of Tropical Medicine and Public Health 36:1407-1411

Uga S, Hoa NT, Noda S, Moji K, Cong L, Aoki Y, et al. (2009) Parasite egg contamination of vegetables from a suburban market in Hanoi, Vietnam. Nepal Medical College Journal 11:75-78

Van CTB, Thuy NTT, San NH, Hien TT, Baranton G, Perolat P (1998) Human leptospirosis in the Mekong Delta, Viet Nam. Transactions of the Royal Society of Tropical Medicine and Hygiene 92:625-628

Van TT, Moutafis G, Istivan T, Tran LT, Coloe PJ (2007) Detection of Salmonella spp. in retail raw food samples from Vietnam and characterization of their antibiotic resistance. Applied and Environment Microbiology 73:6885-6890

Verle P, Kongs A, De NV, Thieu NQ, Depraetere K, Kim HT, et al. (2003) Prevalence of intestinal parasitic infections in northern Vietnam. Tropical Medicine \& International Health 8:961-964

Vien CV, Phue NC, Ha LD, Tuan LM, Van NT, Pao TC, et al. (1997) Paragonimiasis in Sin Ho District, Lai Chau Province, Viet Nam. Southeast Asian Journal of Tropical Medicine and Public Health 28(Suppl 1):46

Vijayan VK (2009) Parasitic lung infections. Current Opinion in Pulmonary Medicine 15:274-282

Vo ATT, van Duijkeren E, Fluit AC, Heck M, Verbruggen A, Maas HME, et al. (2006) Distribution of Salmonella enterica serovars from humans, livestock and meat in Vietnam and the dominance of Salmonella typhimurium phage type 90. Veterinary Microbiology 113:153-158

Vu Nguyen T, Le Van P, Le Huy C, Nguyen Gia K, Weintraub A (2006) Etiology and epidemiology of diarrhea in children in Hanoi, Vietnam. International Journal of Infectious Diseases 10:298-308

Wagenaar JFP, Falke THF, Nam NV, Binh TQ, Smits HL, Cobelens FGJ, et al. (2004) Rapid serological assays for leptospirosis 
are of limited value in southern Vietnam. Annals of Tropical Medicine and Parasitology 98:843-850

Waikagul J, Diaz Camacho P (2007) Gnathostomiasis. In: Foodborne parasitic zoonoses: fish and plant-borne parasites, Fried DMAB (editor), New York: Springer, pp 235-261

Wertheim HF, Nghia HD, Taylor W, Schultsz C (2009) Streptococcus suis: an emerging human pathogen. Clinical Infectious Diseases 48:617-625

Wertheim HF, Nguyen HN, Taylor W, Lien TT, Ngo HT, Nguyen TQ, et al. (2009) Streptococcus suis, an important cause of adult bacterial meningitis in northern Vietnam. PLoS ONE 4:e5973

Willingham AL 3rd, De NV, Doanh NQ, Cong LD, Dung TV, Dorny P, et al. (2003) Current status of cysticercosis in Vietnam. The Southeast Asian Journal of Tropical Medicine and Public Health 34(Suppl 1):35-50

Willingham AL III, Wu H-W, Conlan J, Satrija F (2010) Combating Taenia solium cysticercosis in Southeast Asia: an opportunity for improving human health and livestock production. Advances in Parasitology 72:235-266

Xiao L, Fayer R (2008) Molecular characterisation of species and genotypes of Cryptosporidium and Giardia and assessment of zoonotic transmission. International Journal for Parasitology 38:1239-1255

Xuan LT, Hoa PL, Dekumyoy P, Hoan NH, Khuong LH, Van TT, et al. (2004) Gnathosthoma infection in south Vietnam. Southeast Asian Journal of Tropical Medicine and Public Health 35(Suppl. 1):97-99

Xuan LT, Hung NT, Waikagul J (2005) Cutaneous fascioliasis: a case report in Vietnam. American Journal of Tropical Medicine and Hygiene 72:508-509

Yu H, Jing H, Chen Z, Zheng H, Zhu X, Wang H, et al. (2006) Human Streptococcus suis outbreak, Sichuan, China. Emerging Infectious Diseases 12:914-920 